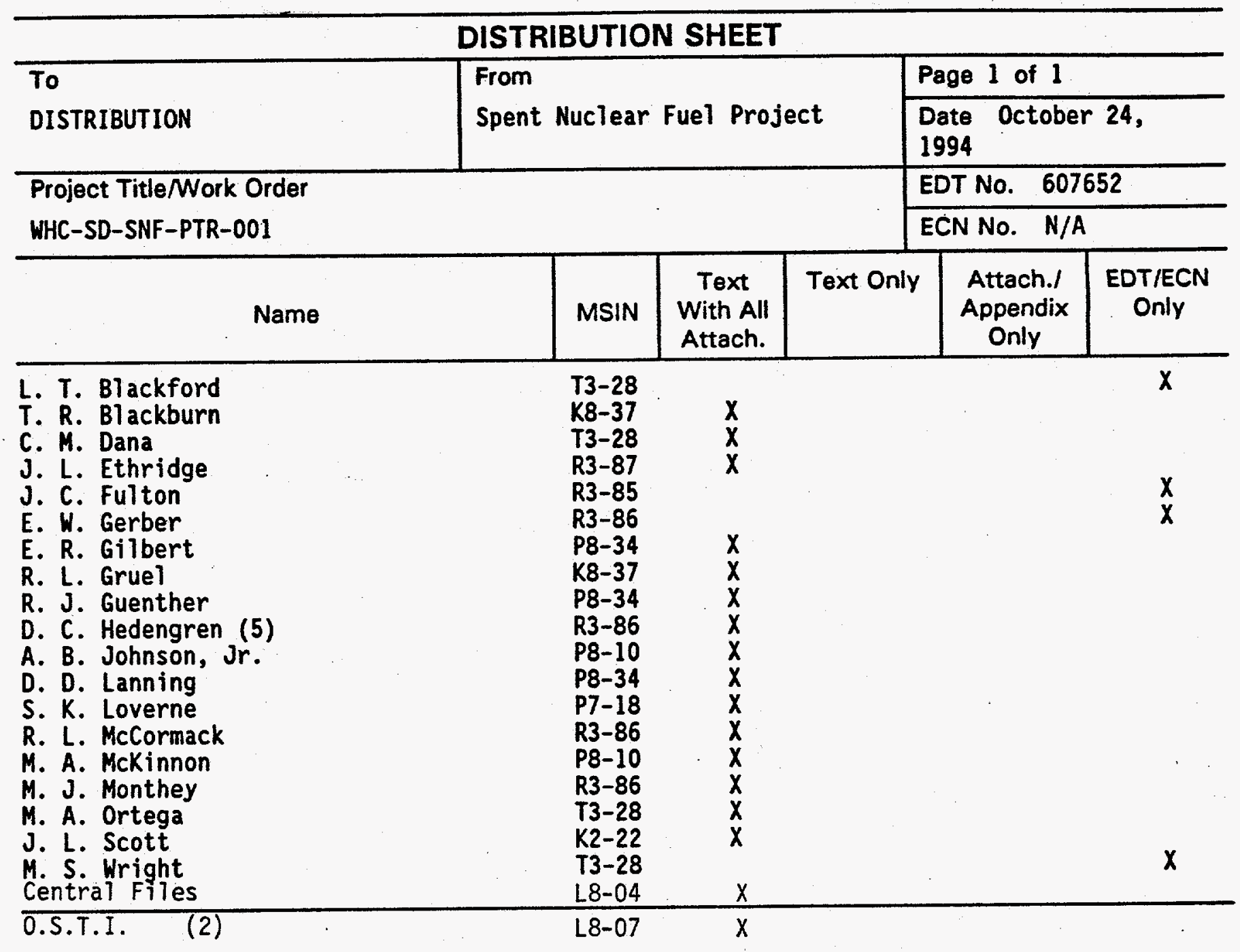




\section{DISCLAIMER}

Portions of this document may be illegible in electronic image products. Images are produced from the best available original document. 
Orgenization)

2. To: CReceiving orgeniz
T-Plant Engineering

5. Proj./Prog./Dept./Div.:

Facility Operations

8. Originator Remarks:

None

\section{Receiver Remarks:}

None
3. From: (originatina organizetion) Engineering Integration

6. cog. Engr.:

D. C. Hedengren
6. Related EDT MO.:

$N / A$

7. Purchase Order Mo.:

$N / A$

9. Equip./Component Mo.:

N/A

10. Systea/Bldg./Facility:

221-T

12. Major Asem. Dwg. Mo.: $N / A$

13. Permit/Pernit Application No.: N/A

14. Required Response Date: N/A

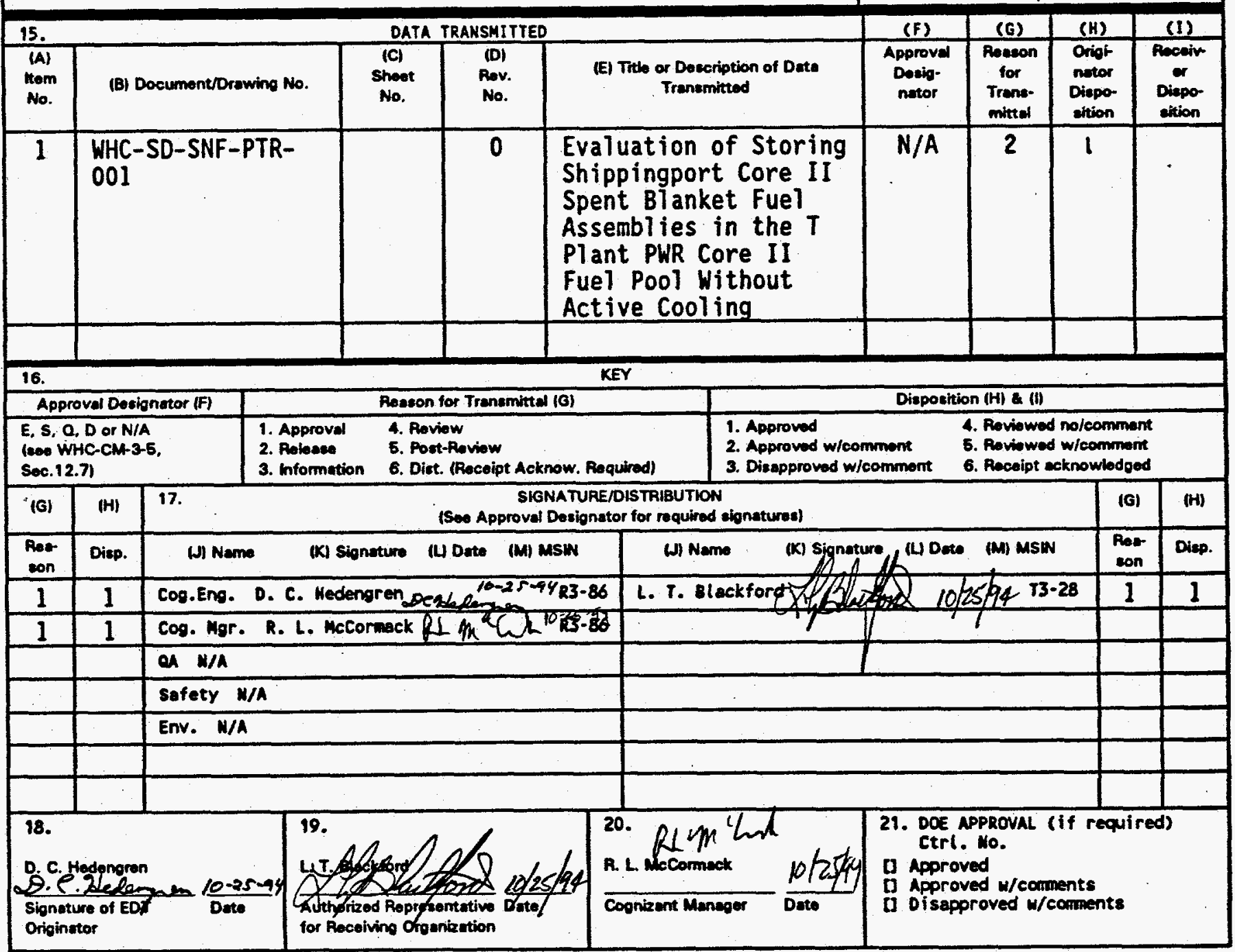

60-7400-172-2 (04/94) GEF097 


\section{RELEASE AUTHORIZATION}

Document Number: WHC-SD-SNF-PTR-001, REV 0

Evaluation of Storing Shippignport Core II Spent Blanket Fuel Assemblies in the T Plant PWR Core II Fuel Pool Without Active Cooling

Release Date: $\quad 10 / 28 / 94$

This document was reviewed following the procedures described in WHC-CM-3-4 and is:

\section{APPROVED FOR PUBLIC RELEASE}

WHC Information Release Administration Specialist:

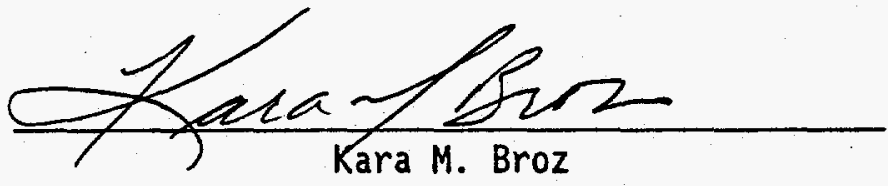

October 28, 1994

TRADEMARK DISCLAIMER. Reference herein to any specific comercial product, process, or service by trade name, trademark, manufacturer, or otherwise, does not necessarily constitute or imply its endorsement. recormendation, or favoring by the United States Government or any agency thereof or its contractors or subcontractors.

This report has been reproduced from the best available copy. Available in paper copy and microfiche. Printed in the United States of America. Available to the U.S. Department of Energy and its contractors from:

U.S. Department of Energy

Office of Scientific and Technical Information (OSTI)

P.0. Box 62

Dak Ridge, IN 37831

Telephone: (615) 576-8401

Ava ilable to the public from:

U.S. Department of Commerce

Mational Technical Information Service (NTIS)

5285 Port Royal Road

Springfield, VA 22161

Telephone: (703) $487-4650$ 
2. Title

Evaluation of Storing Shippingport Core II Spent Blanket Fuel Assemblies in the T Plant PWR Core II Fuel Pool Without Active Cooling

5. Key Words

Irradiated Fue1, Spent Fuel, Shippingport PWR Core II Fuel, PWR Core II, Chiller-off Test

APPROVED FOR

\section{toms $10 / 28$ /94 PUBLIC RELEASE}

3. Nuber

WHC-SD-SNF-PTR-001

4. Rev No.

$\mathbf{0}$

\section{Abstract}

PWR Core II fuel pool chiller-off test was conducted because it appeared possible that acceptable pool-water temperatures could be maintained without operating the chillers, thus saving hundreds of thousands of dollars in maintenance and

replacement costs. Test results showed that the water-cooling capability is no longer needed to maintain pool temperature below $38^{\circ} \mathrm{C}\left(100^{\circ} \mathrm{F}\right)$

8.

RELEASE STAMP

OFFICIAL PELEASE

BYWHIC

DATE OCT 311994 ctan 4 


\title{
Evaluation of Storing Shippingport Core II Spent Blanket Fuel Assemblies in the T Plant PWR Core II Fuel Pool Without Active Cooling
}

\author{
E. R. Gilbert \\ D. D. Lanning \\ C. M. Dana ${ }^{(a)}$ \\ D. C. Hedengren ${ }^{(2)}$
}

October 1994

Prepared for the

Westinghouse Hanford Company

Richland, Washington 99352

Work Supported by the

U. S. Department of Energy

under Contract DE-AC06-76RLO 1830

Pacific Northwest Laboratory

Richland, Washington 99352

(a) Westinghouse Hanford Company, Richland, Washington

\section{DISCLAIMER}

\footnotetext{
This report was prepared as an account of work sponsored by an agency of the United States Government. Neither the United States Government nor any agency thereof, nor any of their employees, makes any warranty, express or implied, or assumes any legal liability or responsibility for the accuracy, completeness, or usefulness of any information, apparatus, product, or process disclosed, or represents that its use would not infringe privately owned rights. Reference herein to any specific commercial product, process, or service by trade name, trademark, manufacturer, or otherwise does not necessarily constitute or imply its endorsement, recommendation, or favoring by the United States Government or any agency thereof. The views and opinions of authors expressed herein do not necessarily state or reflect those of the United States Government or any agency thereof.
} 
WHC-SD-SNF-PTR-001, Rev. 0 


\section{Summary}

Pacific Northwest Laboratory (PNL) developed the test requirements for and evaluated the results of turning off chillers that maintain pool-water temperature in the $190-\mathrm{m}^{3}$ (50,000 gallon) pressurized-water reactor (PWR) Core II fuel pool at Hanford's T Plant in Richland, Washington, where 72 spent Shippingport Core II blanket fuel assemblies are stored. The requirements were developed for Westinghouse Hanford Company, which conducted the test for the U.S. Department of Energy. Test results showed that the watercooling capability is no longer needed. This report describes the test results and provides recommendations for future operation without the chillers.

Before storage of the Shippingport fuel, water chillers (large heat exchangers) were installed at the T Plant to maintain the pool-water temperature at 6 to $12^{\circ} \mathrm{C}\left(45\right.$ to $\left.54^{\circ} \mathrm{F}\right)$ to prevent the fuel assemblies from overheating and to comply with industry's then-current standards and practices for fuel-storage pool operation. However, because of their modest burnup and long decay time, each assembly now produces approximately 100 watts of decay heat $(7.2 \mathrm{~kW}$ total). Furthermore, since the Shippingport assemblies were placed in storage in $1978 / 1979$, industry has raised its recommended fuel-storage, pool-water temperature to 32 to $38^{\circ} \mathrm{C}\left(90\right.$ to $\left.100^{\circ} \mathrm{F}\right)$. PNL's preliminary calculations indicated that the temperature in the PWR Core II fuel pool would remain below this range. The chiller-off test was conducted because it appeared possible that acceptable pool-water temperatures could be maintained without operating the chillers, thus saving hundreds of thousands of dollars in maintenance and replacement costs.

The following operating procedures are recommended for pool operations without active cooling:

- Monitor water temperatures to verify storage at less than $38^{\circ} \mathrm{C}\left(100^{\circ} \mathrm{F}\right)$. Statistical scatter and possible bias in thermocouple readings should be accounted for in setting operating limits.

- Sample water quality twice per month to verify that water quality is within limits. In addition, monitor the content of phosphate and nitrate in the pool water; each should be less than $2 \mathrm{ppm}$. Water quality superior to current limits would be desirable. Consider improving the current cleanup and water turnover rate relative to the industry standard.

- Monitor the water turbidity and algae growth twice monthly by periodic inspection of a visual reference point in the pool and occasional swiping of pool surfaces.

- Do not add chemicals in response to an indication of algae formation without a thorough review of the benefits and potential for new problems. 
WHC-SD-SNE-PTR-001, Rev. 0

The water-cooling capability is no longer needed for the PWR fuel-storage pool as long as no additional heat loads or unreviewed fuel types are added to the pool, the water quality is maintained or improved, and the water quality, radioisotope concentration, and temperatures continue to be monitored. A change to continuous operation of the recirculating pump would be a significant added heat load. 
WHC-SD-SNF-PTR-001, Rev . 0

\section{Acknowledgments}

The authors of this report gratefully acknowledge Sharon K. Loverne of Pacific Northwest Laboratory (PNL) for the technical editing and Hyo C. Morgan for supervising document typing and assembly. 
WHC-SD-SNF-PTR-001, Rev. 0 


\section{Contents}

Summary $\ldots \ldots \ldots \ldots \ldots \ldots \ldots \ldots \ldots \ldots \ldots \ldots \ldots \ldots \ldots \ldots \ldots \ldots$

Acknowledgments $\ldots \ldots \ldots \ldots \ldots \ldots \ldots \ldots \ldots \ldots \ldots \ldots$

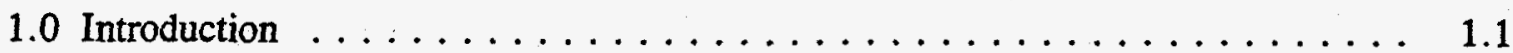

2.0 PWR Core II Fuel Pool $\ldots \ldots \ldots \ldots \ldots \ldots \ldots \ldots \ldots \ldots \ldots \ldots \ldots \ldots$

2.1 Description of the Pool $\ldots \ldots \ldots \ldots \ldots \ldots \ldots \ldots \ldots \ldots \ldots \ldots$

2.2 Description of the Fuel Assemblies . . . . . . . . . . . . . 2.1

2.3 Normal Pool Operation $\ldots \ldots \ldots \ldots \ldots \ldots \ldots \ldots \ldots \ldots$

3.0 Chiller-Off Test Procedures and Results $\ldots \ldots \ldots \ldots \ldots \ldots \ldots \ldots$

3.1 Temperature Measurements $\ldots \ldots \ldots \ldots \ldots \ldots \ldots \ldots \ldots \ldots \ldots$

3.2 Water-Quality Parameters and Radioactivity $\ldots \ldots \ldots \ldots \ldots \ldots . \ldots . . . \ldots$

3.3 Water-Level Measurements $\ldots \ldots \ldots \ldots \ldots \ldots \ldots \ldots \ldots \ldots \ldots$

4.0 Discussion of Results $\ldots \ldots \ldots \ldots \ldots \ldots \ldots \ldots \ldots \ldots \ldots$

4.1 Water-Temperature Behavior $\ldots \ldots \ldots \ldots \ldots \ldots \ldots \ldots \ldots . \ldots \ldots$

4.2 Behavior of Water-Quality Parameters $\ldots \ldots \ldots \ldots \ldots \ldots . \ldots \ldots$

5.0 Conclusions and Recommendations $\ldots \ldots \ldots \ldots \ldots \ldots \ldots \ldots \ldots \ldots$

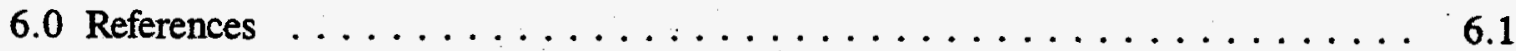

Appendix - Pool-Heating Calculation Worksheets $\ldots \ldots \ldots \ldots \ldots \ldots \ldots$ A.1 
WHC-SD-SNF-PTR-001, Rev. 0

\section{Figures}

2.1 Schematic Drawing of the T Plant PWR Core II Fuel-Storage

Pool (plan views) $\ldots \ldots \ldots \ldots \ldots \ldots \ldots \ldots \ldots \ldots \ldots \ldots \ldots \ldots \ldots \ldots \ldots \ldots .2$

2.2 Schematic Drawing of the T Plant PWR Core II Fuel-Storage

Pool (relative layout) $\ldots \ldots \ldots \ldots \ldots \ldots \ldots \ldots \ldots \ldots \ldots \ldots \ldots \ldots \ldots \ldots . .3$

2.3 Shippingport Core II Blanket Fuel-Assembly Layout $\ldots \ldots \ldots \ldots \ldots \ldots$

2.4 ORIGEN2 Calculations of Shippingport Core II Blanket Assembly Decay

Heat vs. Cooling Time $\ldots \ldots \ldots \ldots \ldots \ldots \ldots \ldots \ldots \ldots \ldots \ldots$

3.1 Location of Thermocouples in the PWR Core II Fuel-Storage Pool . . . . . . . 3.3

3.2 Channel 5 (Top-of-Fuel Rack) Temperatures vs. Time, Compared to Pre-Test Predicted Values for Pool-Water Temperature $\ldots \ldots \ldots \ldots \ldots \ldots \ldots .3 .4$

3.3 Channel 5 and Channel 6 Temperatures vs. Time $\ldots \ldots \ldots \ldots \ldots \ldots$

3.4 Pool Surface Temperatures vs. Time $\ldots \ldots \ldots \ldots \ldots \ldots \ldots \ldots \ldots$

3.5 Water Conductivity vs. Time $\ldots \ldots \ldots \ldots \ldots \ldots \ldots \ldots \ldots \ldots \ldots \ldots \ldots \ldots$

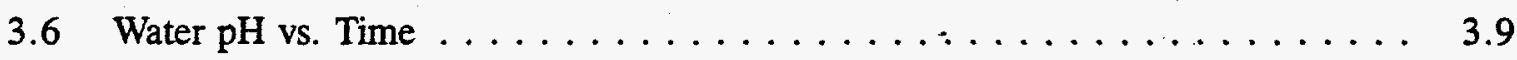

3.7 Water Chloride Concentration vs. Time $\ldots \ldots \ldots \ldots \ldots \ldots \ldots \ldots \ldots$

3.8 Activity of ${ }^{137} \mathrm{Cs}$ in Water vs. Time During the Test . . . . . . . 3.11

3.9 Activity of ${ }^{60} \mathrm{Co}$ in Water vs. Time During the Test $\ldots \ldots \ldots \ldots \ldots \ldots .12$

3.10 Activity of ${ }^{60} \mathrm{Co}$ in Pool Water vs. Time from September 1991 to September 1994, Showing the Effect of Pool Cleaning in $1993 \ldots \ldots \ldots . .13$

3.11 Water Level vs. Time During the Test $\ldots \ldots \ldots \ldots \ldots \ldots \ldots \ldots .14$ 
WHC-SD-SNF-PTR-001, Rev. O

4.1 Estimated Pool Heat Losses, Heat Loads, and Range for Equilibrium

Water Temperatures . . . . . . . . . . . . . . . . . . . . . 4.2

4.2 Revised Predicted Range for Pool-Water Temperatures (with heat load increased to $7.5 \mathrm{~kW}$ ), Compared to Channel 5 Temperatures . . . . . . . . . 4.5

4.3 The Pool-Water pH vs. Time, from September 1991 to September $1994 \ldots$. . . . 4.6

\section{Tables}

2.1 Characteristics of Shippingport Core II Blanket Assemblies

Stored in the T Plant PWR Fuel Pool . . . . . . . . . . . . . . . 2.5

2.2 Comparison of PWR Core II Pool-Water Limits (test conditions) to ANSI/ANS Standard 57.7 (based on GE's Morris pool limits) $\ldots \ldots \ldots \ldots$.

3.1 Comparison of Pre- and Post-Test Detailed Water Analyses) $\ldots \ldots \ldots \ldots$. . . 3.7 
WHC-SD-SNF-PTR-001, Rev. 0 


\subsection{Introduction}

Seventy two spent Shippingport Core II blanket fuel assemblies are stored in racks in the $190-\mathrm{m}^{3}$ (50,000 gallon) pressurized-water reactor (PWR) Core II fuel pool, in Cell 4, at the $T$ Plant in the 200-West Area of the Hanford Site ${ }^{(a)}$ in Richland, Washington. The assemblies contain thin $\mathrm{UO}_{2}$ wafers clad in Zircaloy-4 metal plates. These assemblies were discharged in February 1974 with an average uranium burnup of 1.8 at\% (16,000 MWd/MTU) and have been stored at the T Plant since 1978/1979. Water chillers (large heat exchangers) were installed before storage to maintain the pool-water temperature at 6 to $12^{\circ} \mathrm{C}\left(45\right.$ to $54^{\circ} \mathrm{F}$ ), thereby preventing the fuel assemblies from overheating, precluding algae growth, and complying with then-current industry standards and practices for fuel-storage pool operation (Hanson and Jackson 1978; Johnson 1977).

However, because of their modest burnup and long decay time, each assembly now produces only approximately 100 watts of decay heat $(7.2 \mathrm{~kW}$ total). Also, industry has raised its recommended fuel-storage, pool-water temperature to 32 to $38^{\circ} \mathrm{C}\left(90\right.$ to $\left.100^{\circ} \mathrm{F}\right)$ [American Nuclear Society (ANS) 1988]. In 1992, Westinghouse Hanford Company (WHC) decided to conduct an extended, instrumented test to evaluate the results of turning off the PWR Core II fuel-pool chillers, which would save hundreds of thousands of dollars in operation, maintenance, and replacement costs. WHC commissioned Pacific Northwest Laboratory (PNL) ${ }^{(b)}$ to develop the test requirements and evaluate the results.

Before the test, which was conducted from May 17 through September 1, 1994, WHC cleaned the pool, installed additional water thermocouples, and intensified water-sampling and analysis procedures. During the test, water temperatures in four locations were continuously recorded on a data acquisition system, and the water was sampled and analyzed twice weekly for conductivity, $\mathrm{pH}$, chloride and fluoride content, and radioisotope concentration (e.g., ${ }^{137} \mathrm{Cs}$ and ${ }^{60} \mathrm{Co}$ activity). High ambient air temperatures within the canyon [up to $30^{\circ} \mathrm{C}\left(86^{\circ} \mathrm{F}\right)$ ] during the test were expected to maximize the equilibrium water temperatures.

Maximum equilibrium water temperatures were less than $31^{\circ} \mathrm{C}\left(88^{\circ} \mathrm{F}\right)$, which is below accepted limits for reactor fuel-storage pools with Zircaloy and stainless-steel-clad oxide fuels. ${ }^{(c)}$ The measured water quality and radioisotope concentration remained within established limits and, in fact, did not significantly change within the 3.5-month test period. There

(a) The Hanford Site is operated for the U.S. Department of Energy by Westinghouse Hanford Company.

(b) PNL is operated for the U.S. Department of Energy by Battelle Memorial Institute.

(c) Hanford T Plant Engineering. 1994. "Pressurized Water Reactor (PWR) Chiller Off Test Final Report." Letter No. 87430-94-LTB-004, Hanford T Plant Engineering to D. C. Hedengren (WHC) August 26, 1994, Westinghouse Hanford Company, Richland, Washington. 
was no evidence of algae growth. Thus the water-cooling capability is no longer needed for the PWR fuel-storage pool as long as additional heat loads or unreviewed fuel types are not added to the pool, the water quality is maintained or improved, and the water quality, radioisotope concentration, and temperatures continue to be monitored.

A description of the PWR pool, its auxiliary equipment, and the Shippingport fuel assemblies are presented in Section 2.0. The test procedures and results are described in Section 3.0 and discussed in Section 4.0. Conclusions and recommendations are given in Section 5.0, and the references are listed in Section 6.0. The assumptions and procedures used for pretest water-temperature predictions are presented in the appendix. 


\subsection{PWR Core II Fuel Pool}

The features of the Cell 4 PWR Core II fuel pool, the features of the PWR Core II blanket fuel assemblies, and the conditions of normal fuel operation are described in this section.

\subsection{Description of the Pool}

The Cell 4 PWR Core II fuel pool is an unlined, concrete water pool with inner dimensions of $4.0 \times 8.4 \times 8.5$ meters ( $13 \mathrm{ft}$ wide by $27.67 \mathrm{ft}$ long and $28 \mathrm{ft}$ deep). The typical water depth is $5.79 \pm 0.06$ meters $(19 \pm 0.2 \mathrm{ft})$. The concrete sides vary in thickness from 2.1 to 3.3 meters ( 7 to $\sim 11 \mathrm{ft}$ ), as shown in Figure 2.1. The bottom side, which is $\sim 2$ meters $(6 \mathrm{ft})$ thick, rests on a sand liner in contact with earth, but the four walls are partially in contact with ambient air, as shown in Figure 2.2.

The water was cooled by two $37-\mathrm{kW}(126,000 \mathrm{Btu} / \mathrm{hr})$ heat exchanger systems (one active, one on standby). Simple evaporation from the pool surface constitutes a passive heat-removal mechanism. At the nominal cooled pool temperatures, the evaporation rate is about $0.014 \mathrm{~mL} / \mathrm{m}^{2}$ per second ( 0.03 gallon per square foot per day), which corresponds to a heat removal rate of $1.5 \mathrm{~kW}$. This passive evaporation-related heat removal rate increases by a factor of 5 as the pool-water temperature approaches $38^{\circ} \mathrm{C}\left(100^{\circ} \mathrm{F}\right)$. At elevated pool temperatures there is also heat loss through the concrete walls into the environment, which approaches $5 \mathrm{~kW}$ as the water temperatures approach $38^{\circ} \mathrm{C}$. The convective heat transfer with the air above the pool is negligible.

The heat loads on the pool include the decay heat from the fuel $(7.2 \mathrm{~kW})$ and the heat added by the support systems pumps. ${ }^{(a)}$ The pump for the ion exchange unit now runs continuously and adds approximately $0.3 \mathrm{~kW}$ to the heat load. A recirculation pump in the filtration system is run intermittently and, while running, adds about $2 \mathrm{~kW}$.

\subsection{Description of the Fuel Assemblies}

The fuel assemblies come from the blanket region of Core II of the Shippingport PWR. A complete assembly consists of a bottom extension region, the fuel cluster region, and the top extension region, as shown in Figure 2.3. The overall length is 3.6 meters (142 in.);

(a) D. C. Hedengren. 1994. "Meeting Minutes--PWR Core II Chiller-Off Test (7-25-94)." Memo from D.C. Hedengren to Distribution July 28, 1994, Westinghouse Hanford Company, Richland; Washington. 


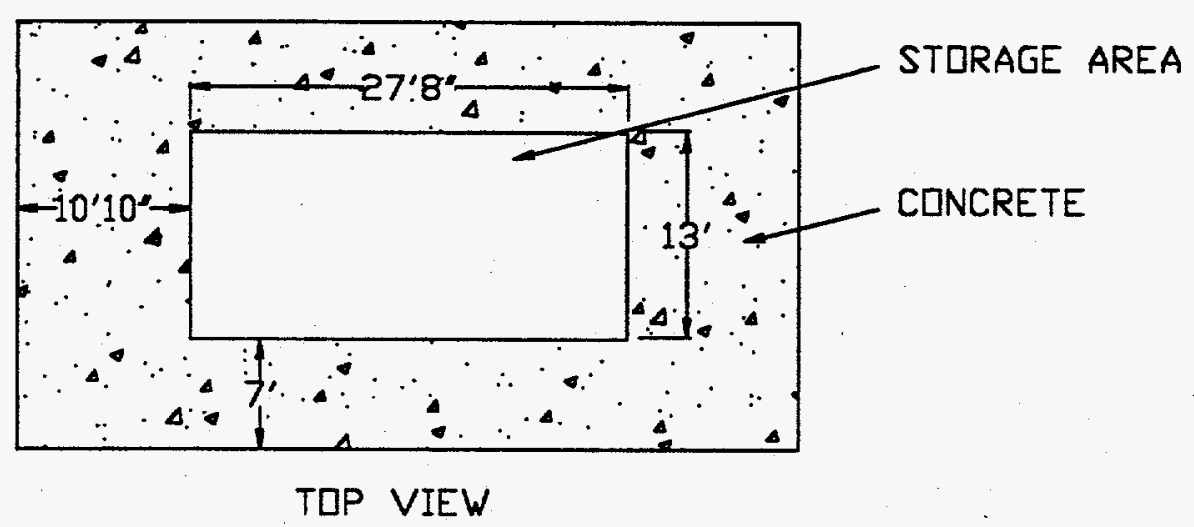

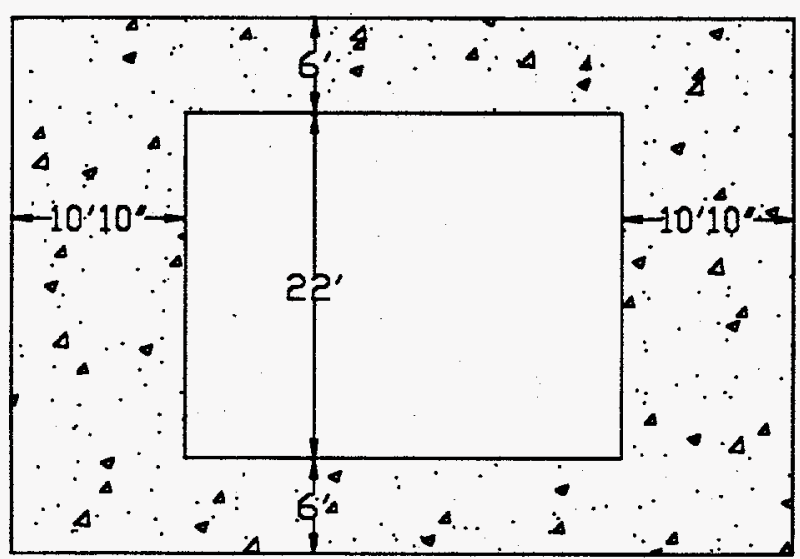

SIDE VIEW

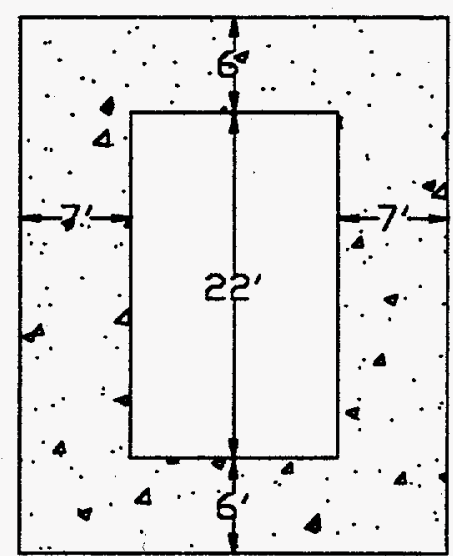

END VIEW

Figure 2.1. Schematic Drawing of the T Plant PWR Core II Fuel-Storage Pool (plan views)

however, the fueled length is only 2.45 meters $(96.5 \mathrm{in}$.). The assemblies are constructed as two subassemblies welded side by side. Each subassembly contains 30 fuel plates and two side plates. Each Zircaloy-4 clad fuel plate in turn contains a large number of depleted sintered uranium dioxide fuel wafers, as indicated in Figure 2.3. Further dimensions and other details on the plate fuel are given in Table 2.1. Predicted assembly decay heat is shown as a function of time in Figure 2.4. The majority of the heat is generated in the uranium oxide fuel. The fuel wafers within each fuel plate are pneumatically interconnected, such that fuel oxidation from a leak in a plate could propagate. Also while the plate cladding is made of corrosion-resistant Zircaloy-4, the extension pieces are made of stainless steel, which could be somewhat sensitized to degradation by chloride 


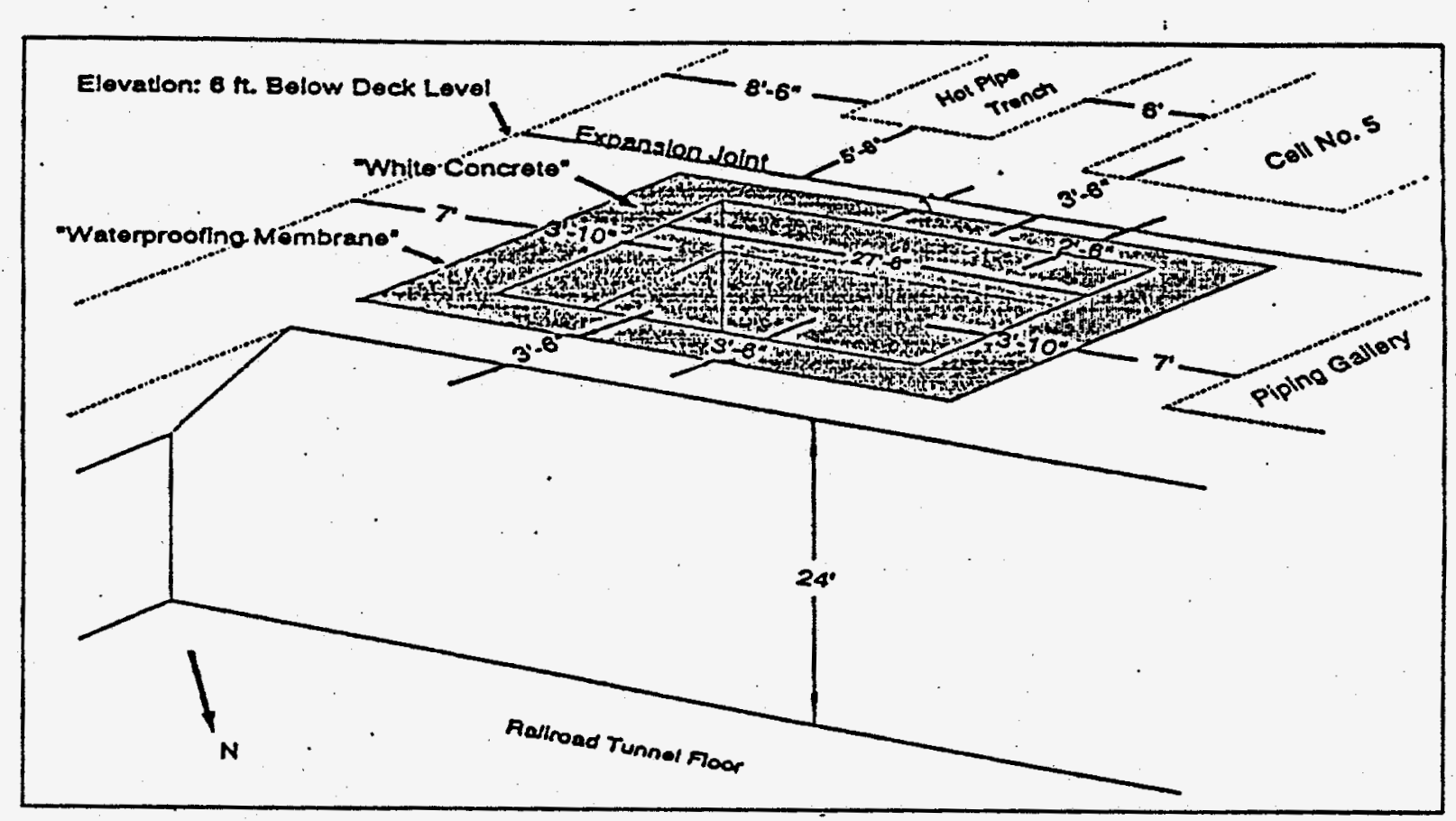

Figure 2.2. Schematic Drawing of the T Plant PWR Core II Fuel-Storage Pool (relative layout)

contamination, especially in transition weld areas. This means that maintenance of low chloride concentration in the storage-pool water is desirable.

\subsection{Normal Pool Operation}

In normal operation, the pool height reduces from 5.79 meters $(19.0 \mathrm{ft})$ by 0.09 meters $(0.3 \mathrm{ft})$ every 2 to 3 months due to evaporation. (a) At that point, sufficient deionized water is injected into the pool to bring the pool depth up to the 5.79-meter (19.0 foot) nominal value. The normal operation of the PWR fuel pool also includes the following activities:

- Maintain water temperature at 6 to $12^{\circ} \mathrm{C}$.

(a) As discussed in Section 4.0, the water-loss rates both before and during the test are consistent with expected evaporation rates. 
WHC-SD-SNF-PTR-001, Rev. 0

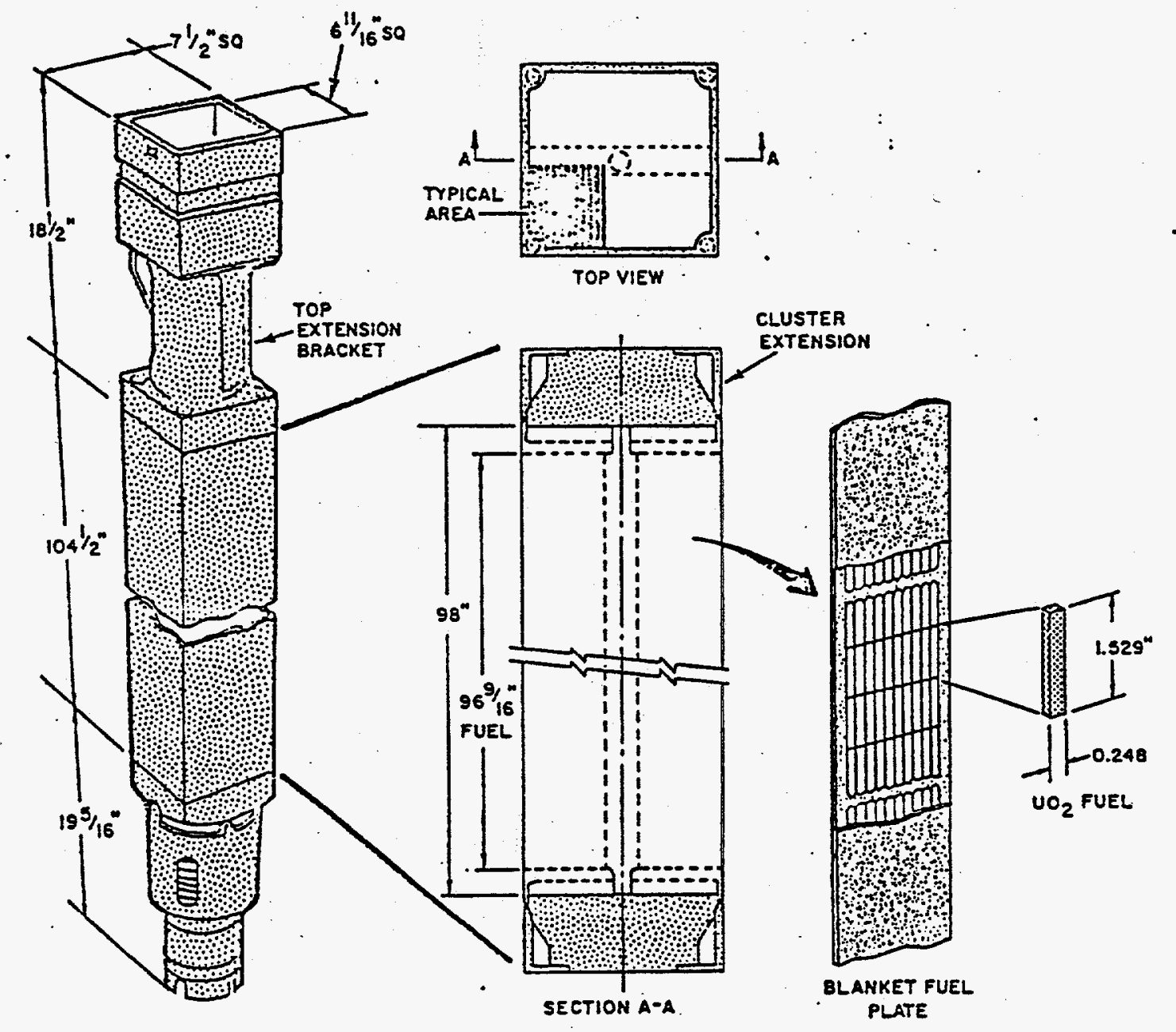

Figure 2.3. Shippingport Core II Blanket Fuel-Assembly Layout 
Table 2.1. Characteristics of Shippingport Core II Blanket Assemblies Stored in the T Plant PWR Fuel Pool

\begin{tabular}{lc}
\multicolumn{1}{c}{ Parameter and units } & \multicolumn{1}{c}{ Values } \\
\cline { 1 - 1 } $\begin{array}{l}\text { Number of fuel assemblies } \\
\text { Average uranium burnup, }\end{array}$ & 72 \\
MWd/MTU & 16,000 \\
Decay time (2/4/94), years & 20.0 \\
$\begin{array}{l}\text { Decay heat, W/assembly } \\
\text { (as calculated from ORIGEN2) }\end{array}$ & \\
20 years decay & \\
30 years decay & 104 \\
Assembly length, meters (inches) & 89 \\
Active length, meters (inches) & $3.61(142.3)$ \\
Assembly width (square) mm & $2.369(93.25)$ \\
(inches) & $187(7.376)$ \\
Plate width, mm (inches) \\
(this is active/fueled width) \\
Plate thickness, mm (inches) \\
$\begin{array}{l}\text { Cladding wall, mm (inches) } \\
\text { Water channel, mm (inches) }\end{array}$
\end{tabular}

- Maintain the following permitted water quality limits (by continuous operation of a $0.63-\mathrm{L} / \mathrm{s}(10 \mathrm{gpm})$ ion exchange filtration system):

- conductivity $<29 \mu \mathrm{mho} / \mathrm{cm}$ (normal range $<26$ )

- $\mathrm{pH}$ in the range 4.5 to 9.6 (normal range is 6 to 8 )-chloride concentration $<5 \mathrm{ppm}$ (normal <2)

- fluoride concentration (not specifically limited) (normally $<2$ ppm) 
WHC-SD-SNF-PTR-001; Rev. 0

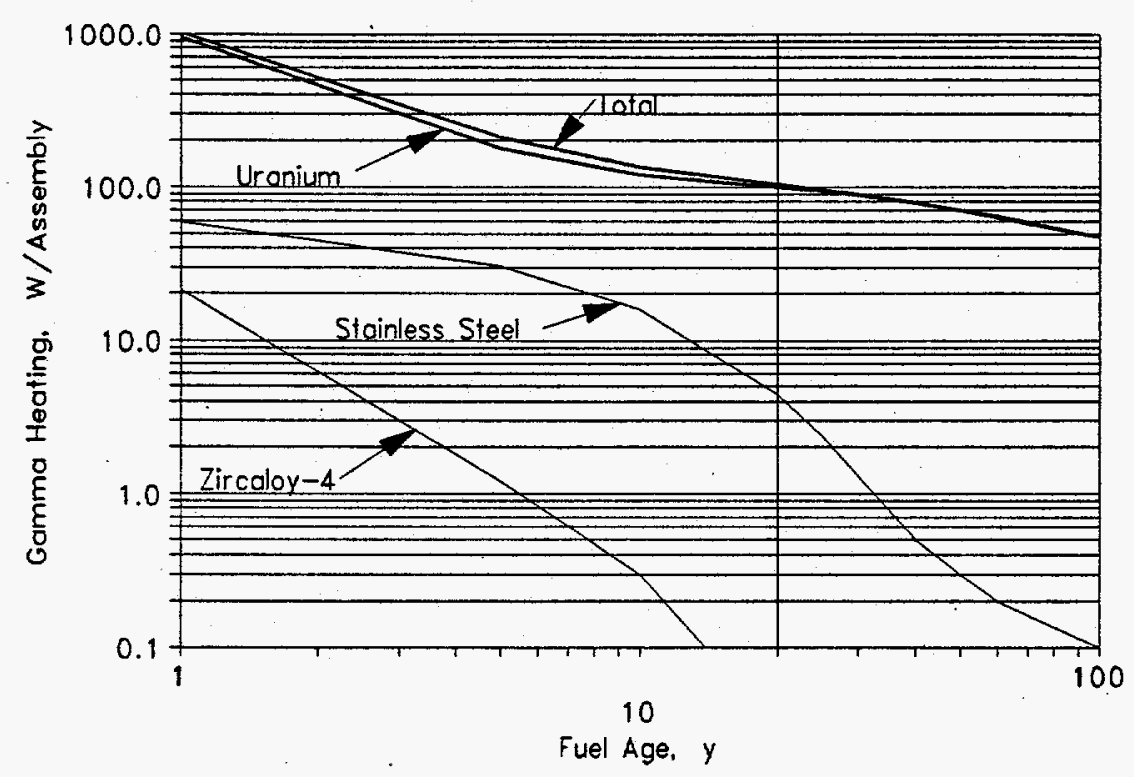

Figure 2.4. ORIGEN2 Calculations (Morford 1988) of Shippingport Core II Blanket Assembly Decay Heat vs. Cooling Time [heat generation rate in uranium $\left(\mathrm{UO}_{2}\right)$, stainless steel, and Zircaloy-4] (time after discharge on February 4, 1974)

- ${ }^{60} \mathrm{Co}$ activity plus ${ }^{137} \mathrm{Cs}$ activity $<1 \times 10^{-3} \mu \mathrm{Ci} / \mathrm{mL}$ (normal is $<1.5 \times 10^{-4} \mu \mathrm{Ci} / \mathrm{mL}$, $>99 \%$ Cobalt activity).

- Verify water quality: bi-weekly samples and analysis.

The water quality standards are compared to those for the General Electric (GE) fuel pool located in Morris, Illinois, in Table 2.2. The latter is the basis for the industry standard for fuel-pool operation [American Nuclear Society (ANS) 1988]. As can be seen, the PWR Core II fuel-pool standards are less stringent than those for GE's Morris pool. Thus, the acceptability of operating at elevated temperatures in the PWR core II fuel pool could not be judged by simple reference to the excellent experience at Morris. The results of the chiller-off test were needed to confirm the calculated equilibrium pool temperatures. These results were also needed to determine the effect of combined higher water temperatures and less stringent water quality limits on the pool and fuel condition. 
WHC-SD-SNF-PTR-001, Rev. 0

Table 2.2. Comparison of PWR Core II Fuel Pool-Water Limits and Test Conditions to ANSI/ANS Standards (based on GE's Morris pool limits)

ANS Standard, Based on

Current PWR Core II

Parameter and Units

Maximum water temperature, ${ }^{\circ} \mathrm{F}$

$\mathrm{pH}$

Conductivity, $\mu \mathrm{mho} / \mathrm{cm}$

Impurity levels, ppm

${ }^{134} \mathrm{Cs} /{ }^{137} \mathrm{Cs}$ activity, $\mu \mathrm{Ci} / \mathrm{mL}$

${ }^{60} \mathrm{Co}$ activity, $\mu \mathrm{Ci} / \mathrm{mL}$
Fuel Pool Limits

$<100$ (in test)

45 to 54 (normal operation)

4.5 to 9.6

$<29$

$<5 \mathrm{Cl}$

$*$

*
GE's Morris Pool

Conditions

90 in normal operation, $<110$ more than $5 \%$ of time during 4 warmest months

5.8 to 6

$<1$

$<1$, all impurities

$1 \times 10^{-3}$

$1 \times 10^{-3}$

* The limit for the sum of all radionuclides is $1 . \times 10^{-3} \mu \mathrm{Ci} / \mathrm{mL}$. 
WHC-SD-SNF-PTR-001, Rev. 0

2.8 


\subsection{Chiller-Off Test Procedures and Results}

In 1993, before the chiller-off test, the accessible surfaces within the fuel pool were mechanically cleaned. Three Type $J$ thermocouples were installed, in addition to the one (near-surface) thermocouple already in use, for monitoring water temperatures. All four thermocouples were connected to a data-logging device with the following correlation between approximate location and channel number designations:

Channel 3 - previous probe installed (near surface, at side, away from fuel racks)

Channel 4 - near surface (above fuel)

Channel 5 - just above fuel storage racks

Channel 6 - pool bottom (very near bottom surface), near fuel storage racks.

These thermocouple locations are indicated in the sketch in Figure 3.1.

The water sampling locations remained unchanged (a dip sample from the pool near the surface and one near the side and a stream sample from the line coming from the ion exchanger). However, the sampling frequency was increased from twice per month to twice per week. In addition, a water sample was taken from just above the fuel racks and sent to PNL for detailed analyses, including an ICP analysis for trace cations and a survey for all common anions, including tritium. A water sample taken at the end of the test provided data for comparison with results from samples taken earlier before and during the test.

\subsection{Temperature Measurements}

The chillers were turned off on May 17, 1994, and have remained off. The official time period of the chiller-off test is defined as May 17 to September 1, 1994. As predicted by pretest thermal calculations, ${ }^{\left({ }^{2}\right)}$ the water temperatures rose slowly over the 3.5 -month test period and reached an equilibrium level of less than $31^{\circ} \mathrm{C}\left(88^{\circ} \mathrm{F}\right)$. The thermocouple readings were tabulated every 4 hours during the test.

The maximum measured temperatures came from the Channel 5 thermocouple, located just above the fuel racks. The data from this thermocouple together with the range of the pretest

(a) E. R. Gilbert and D. D. Lanning. 1992. "Interim Report on T Plant Chiller Option Task." Letter from E. R. Gilbert (PNL) to D. C. Hedengren (WHC) December 7, 1992, Pacific Northwest Laboratory, Richland, Washington. 
predictions are shown in Figure 3.2. The measured temperatures were near the upper bound of the predicted temperatures. These pretest predictions did not include the heat load from the filtration system pump $(0.3 \mathrm{~kW})$ and contained an underestimate of the summertime air temperature on the outside of the concrete pool walls. Corrections for these deficiencies bring even closer agreement between measured and predicted temperatures, as discussed in Section 4.0.

A small temperature increase from the bottom to the top of the fuel racks was expected, because of natural convection-current cooling flow within the fuel assemblies. The expected temperature difference is a function of the velocity (unknown) of the natural circulation. Estimating this velocity leads to temperature differences of approximately 1 to $3^{\circ} \mathrm{C}$ ( 2 to $6^{\circ} \mathrm{F}$ ). The measured temperature difference between the top and the bottom of the fuel racks is found by comparing Channel 6 data to that from channel 5 , as shown in Figure 3.3. The large oscillations in the Channel 6 (pool bottom) temperatures indicated in Figure 3.3 are correlated with intermittent operation of the recirculation pump. It is suspected that recirculation currents may have caused thermocouple contact with the pool floor, leading to spuriously low readings. The smaller oscillations in these temperatures, with periods of approximately one day, have not been fully explained. The maximum difference recorded was about $6^{\circ} \mathrm{F}$, but this was reduced after about August 10. This reduction was a consequence of moving the cleanup system pump from the mid pool position to the bottom of the pool, which occurred on August 10, plus its almost constant operation thereafter; the pump action disturbed the weak natural circulation current.

The pool near-surface temperatures (from the thermocouples connected to Channels 3 and 4) are plotted vs. time in Figure 3.4. These surface temperatures rose with time during the test but showed less variability (less sensitivity to pump operations) than the temperatures measured deeper in the pool. The fuel temperature variations are presented in Section 4.0.

The concentrations of anions, cations, and tritium found in detailed pre-test and post-test water analyses are compared in Table 3.1. Within detection and analysis limitations, no change in these concentrations or in water conductivity were found as a result of the chiller-off operation. Note that sodium (at a very low concentration) was the only cation found in the pre-test sample, although approximately 50 common elements were scanned by ICP, with detection limits at 0.01 to $0.05 \mathrm{ppm}$ typically. Cations were not analyzed in the post-test sample.

\subsection{Water-Quality Parameters and Radioactivity}

Even though the temperatures rose significantly during the testing period, there was little change in the water-quality parameters. This is demonstrated by the following plots of measured parameter values vs. time after start of test: conductivity (Figure 3.5), pH (Figure 3.6), and chloride concentration (Figure 3.7). These parameters did not vary systematically or significantly during the test period. 
WHC-SD-SNF-PTR-001, Rev. 0

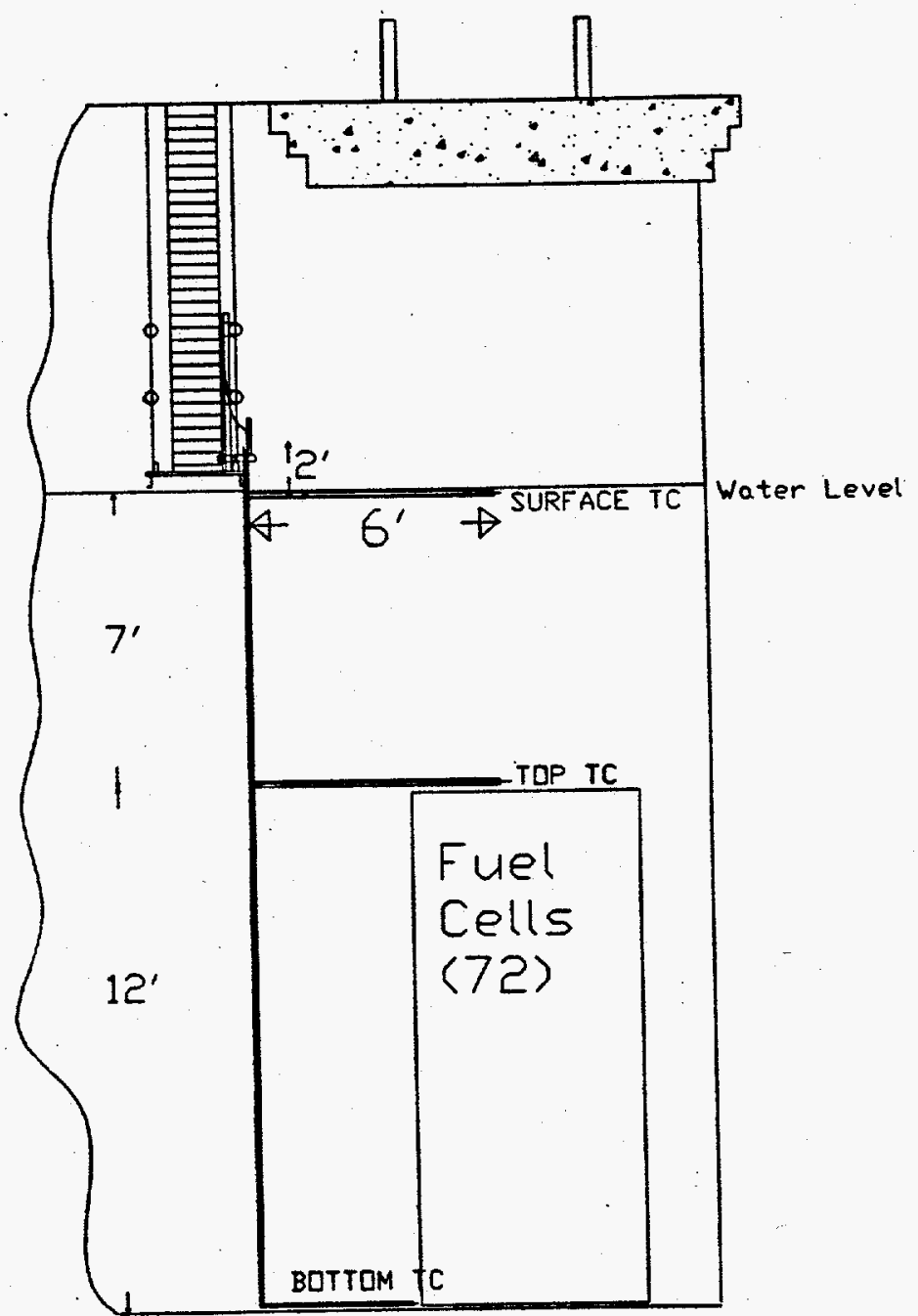

Figure 3.1. Location of Thermocouples in the PWR Core II Fuel-Storage Pool 
WHC-SD-SNE-PTR-001, Rev. 0

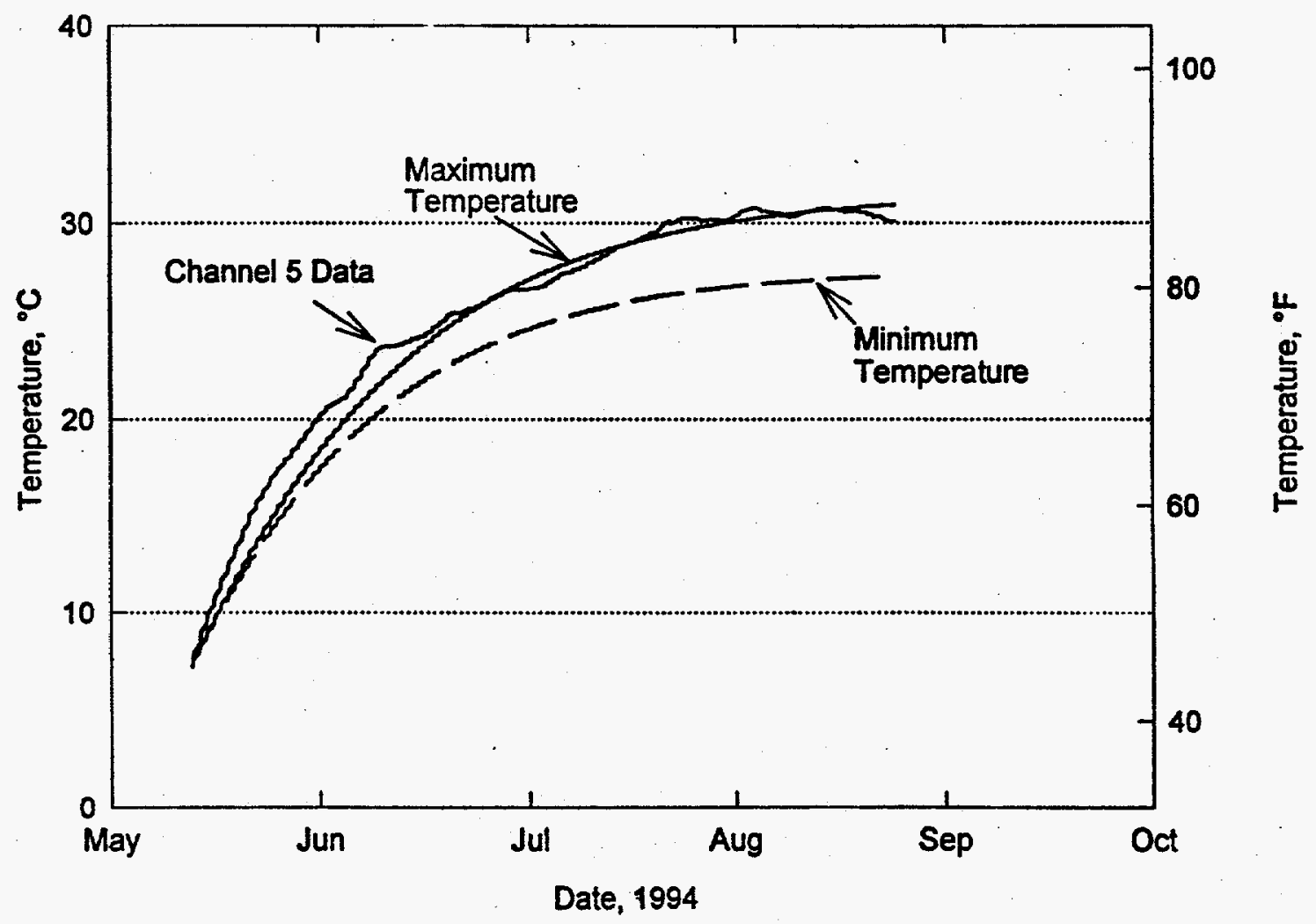

Figure 3.2. Channel 5 (Top-of-Fuel Rack) Temperatures vs. Time, Compared to Pre-Test Predicted Values for Pool-Water Temperature (Prediction Range Indicated by the Curves Labelled "Max. Temp." and "Min. Temp.") 
WHC-SD-SNF-PTR-001， ReV. 0

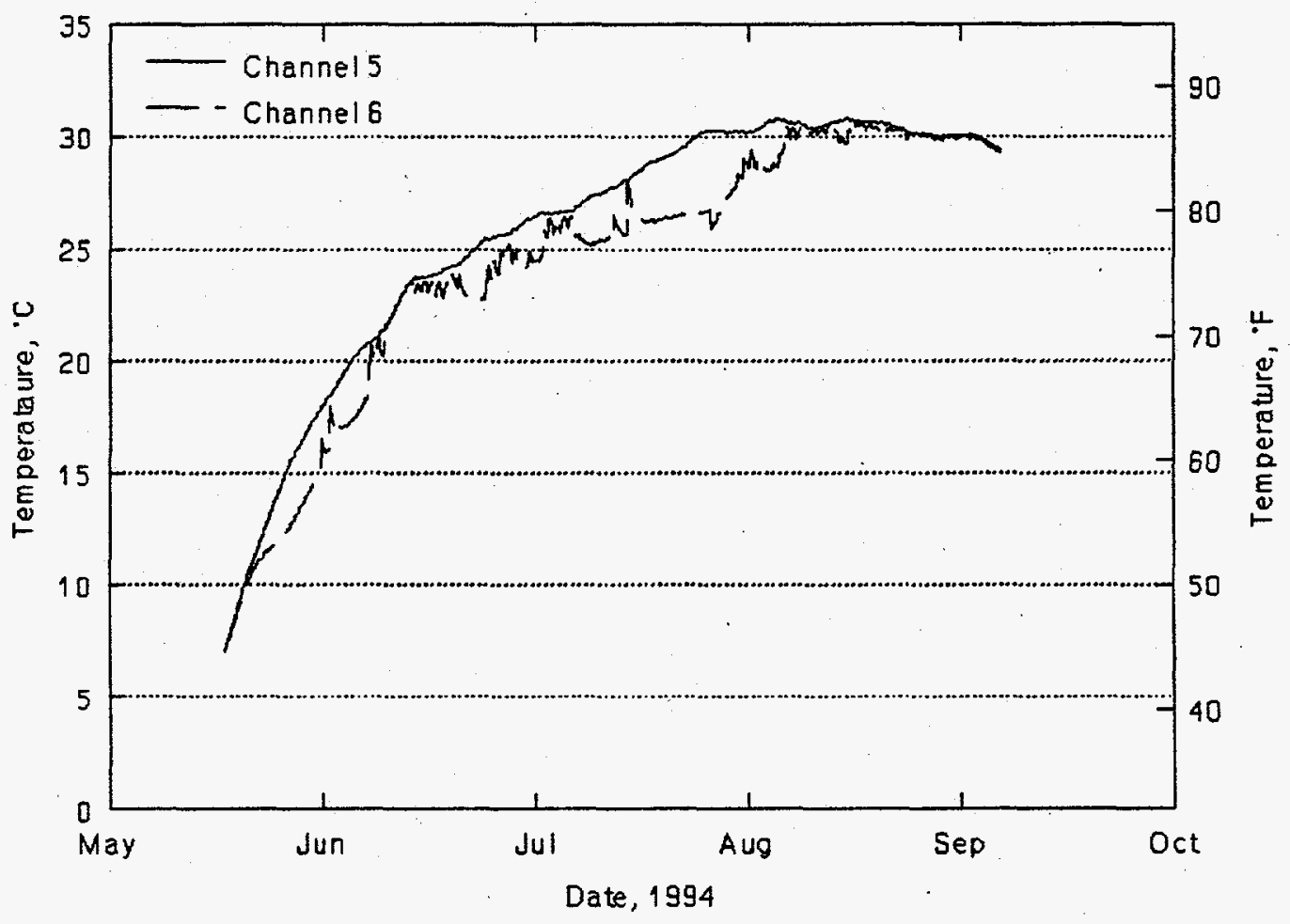

mussou

Figure 3.3. Channel 5 and Channel 6 Temperatures vs. Time (top of rack compared to bottom of rack)

The concentrations of the two reported radioactive isotopes $\left({ }^{137} \mathrm{Cs}\right.$ and $\left.{ }^{60} \mathrm{Co}\right)$ are plotted vs. time in Figures 3.8 and 3.9, respectively. There is no systematic or significant variation to the ${ }^{137} \mathrm{Cs}$ activity. The rise in ${ }^{60} \mathrm{Co}$ activity near the end of the test may have resulted from the movement of the filtration system pump to the bottom of the pool on August 10 and a consequent change in the water flow pattern. The cleaning performed before the chiller-off test raised the ${ }^{60}$ Co activity by an order of magnitude relative to pre-cleaning values (see Figure 3.10). This was presumed to be due to disturbance of activity-bearing deposits built up over years of fuel storage. The surface of the fuel plates is expected to contain some activity-bearing, ionic "crud" deposits that over extended time could, in limited terms, migrate by physical and chemical processes to other surfaces within the pool. The total activity in the water, however, still remains well below the limit of $1 \times 10^{-3} \mu \mathrm{Ci} / \mathrm{mL}$. 
WHC-SD-SNF-PTR-001，Rev. 0

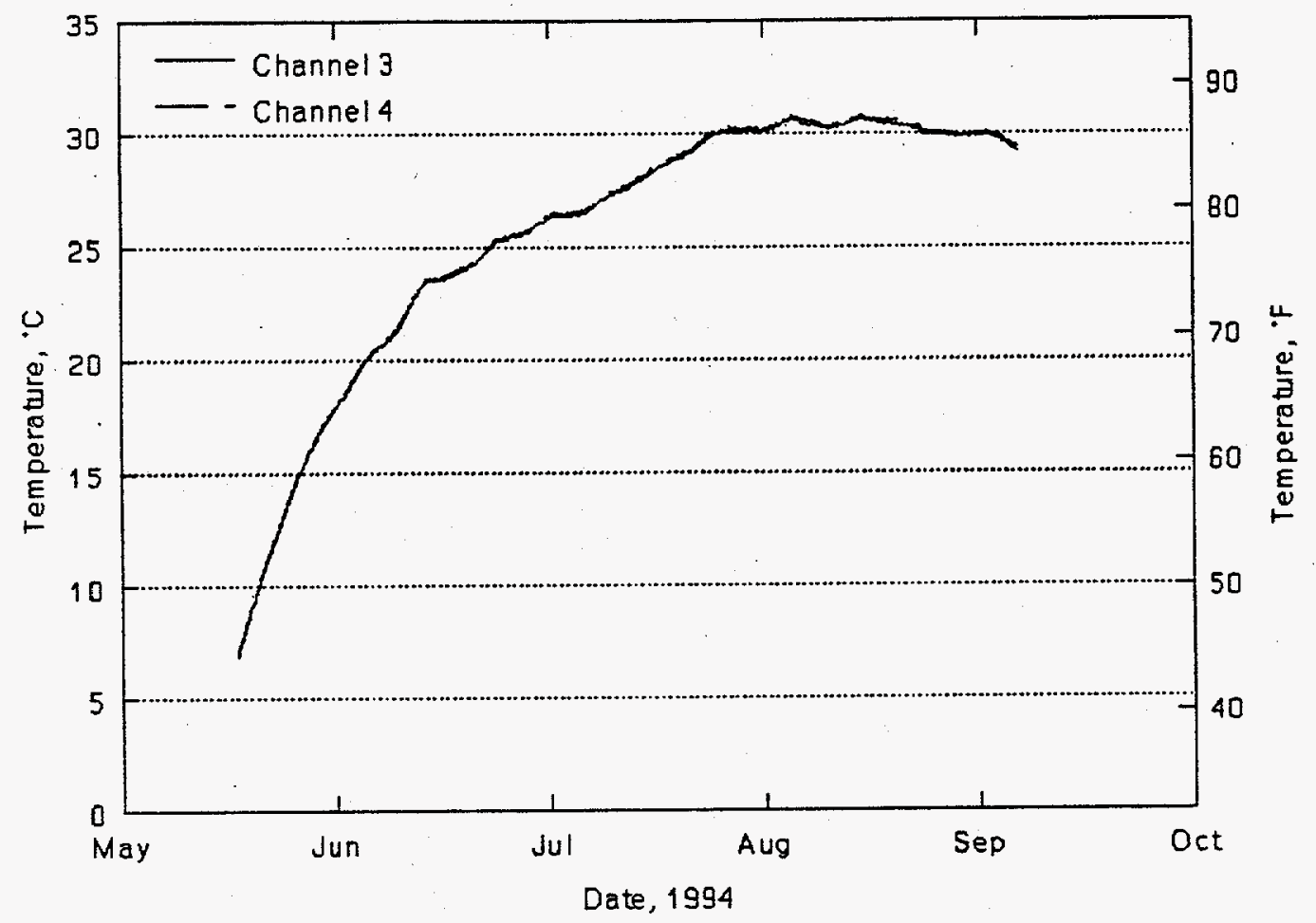

Figure 3.4. Pool Surface Temperatures vs. Time (Channels 3 and 4)

No direct analytical assessment of bacteria or algae growth was made on the water samples taken during the test. However, due to lack of nutrient and limited lighting, no such growth was expected. As judged by visual references within the pool, water turbidity did not increase and surface slime did not develop within the testing period.

The behavior of the water quality parameters and radioactivity is presented in Section 4.0. 
WHC-SD-SNF-PTR-001，Rev. 0

Table 3.1. Comparison of Pre- and Post-Test Detailed Water Analyses

\begin{tabular}{|c|c|c|}
\hline Element & Pre-Test Concentration, $\mathrm{ppm}^{(2)}$ & Post-Test Concentration, $\mathrm{ppm}^{(b)}$ \\
\hline $\mathrm{Cl}$ & 1.6 & 1.6 \\
\hline F & $<0.25$ & $<1.6$ \\
\hline $\mathrm{PO}_{4}$ & $<0.5$ & $<1.5$ \\
\hline $\mathrm{NO}_{3}$ & $<0.5$ & $<1.8$ \\
\hline $\mathrm{SO}_{4}$ & $<0.5$ & $<1.8$ \\
\hline $\mathrm{NO}_{2}$ & $<0.5$ & NA \\
\hline $\mathrm{Br}$ & $<0.25$ & NA \\
\hline $\mathrm{Na}$ & 5 & NA \\
\hline${ }^{3} \mathrm{H}$ & 20 to $70 \mathrm{picoCi} / \mathrm{mL}$ & $<5.2 \mathrm{picoCi} / \mathrm{mL}$ \\
\hline
\end{tabular}

(a) Performed at the PNL Analytical Chemistry Laboratories, 300 Area.

(b) Performed at the WHC 222-S Laboratory, 200-W Area.

\subsection{Water-Level Measurements}

Water level (depth) in Channel 1 of the recorder was recorded continuously during the test. These data are shown vs. time in Figure 3.11. The sharp rises in water levels around July 26 and August 26 are due to deliberate water additions to maintain the pool at the nominal $5.8-\mathrm{m}(19-\mathrm{ft})$ depth. The water-level decrease is due to evaporation. The rate of depth decrease increased in response to the water temperature rise during the test, as predicted. The magnitude of that rate increase, and its current equilibrium value, is consistent with the equations used for evaporation rate, as discussed in Section 4.0. 
WHC-SD-SNF-PTR-001, Rev. 0

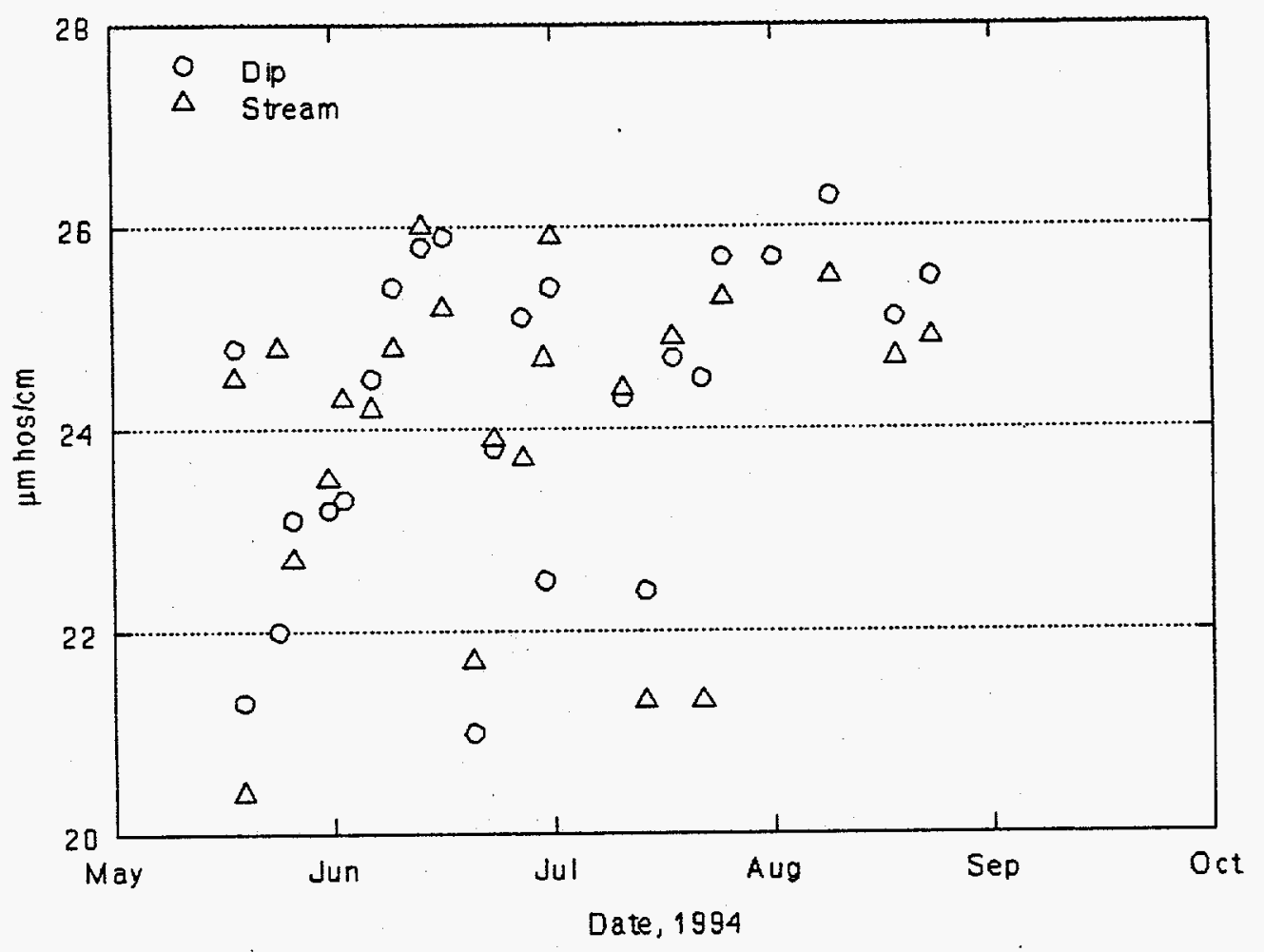

Figure 3.5. Water Conductivity vs. Time 
WHC-SD-SNF-PTR-001, Rev. 0

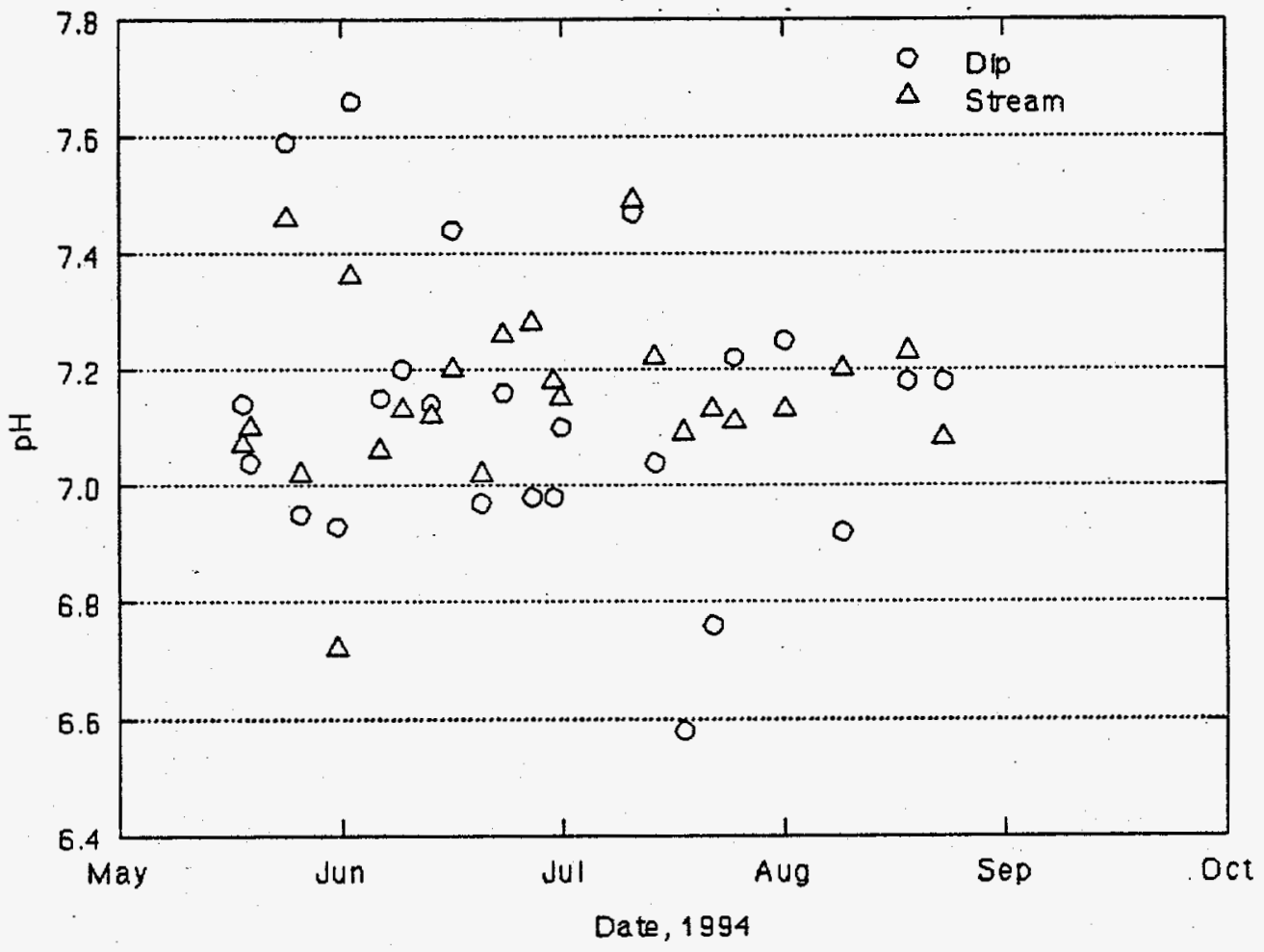

Figure 3.6. Water $\mathrm{pH}$ vs. Time 
WHC-SD-SNF-PTR-001， Rev. 0

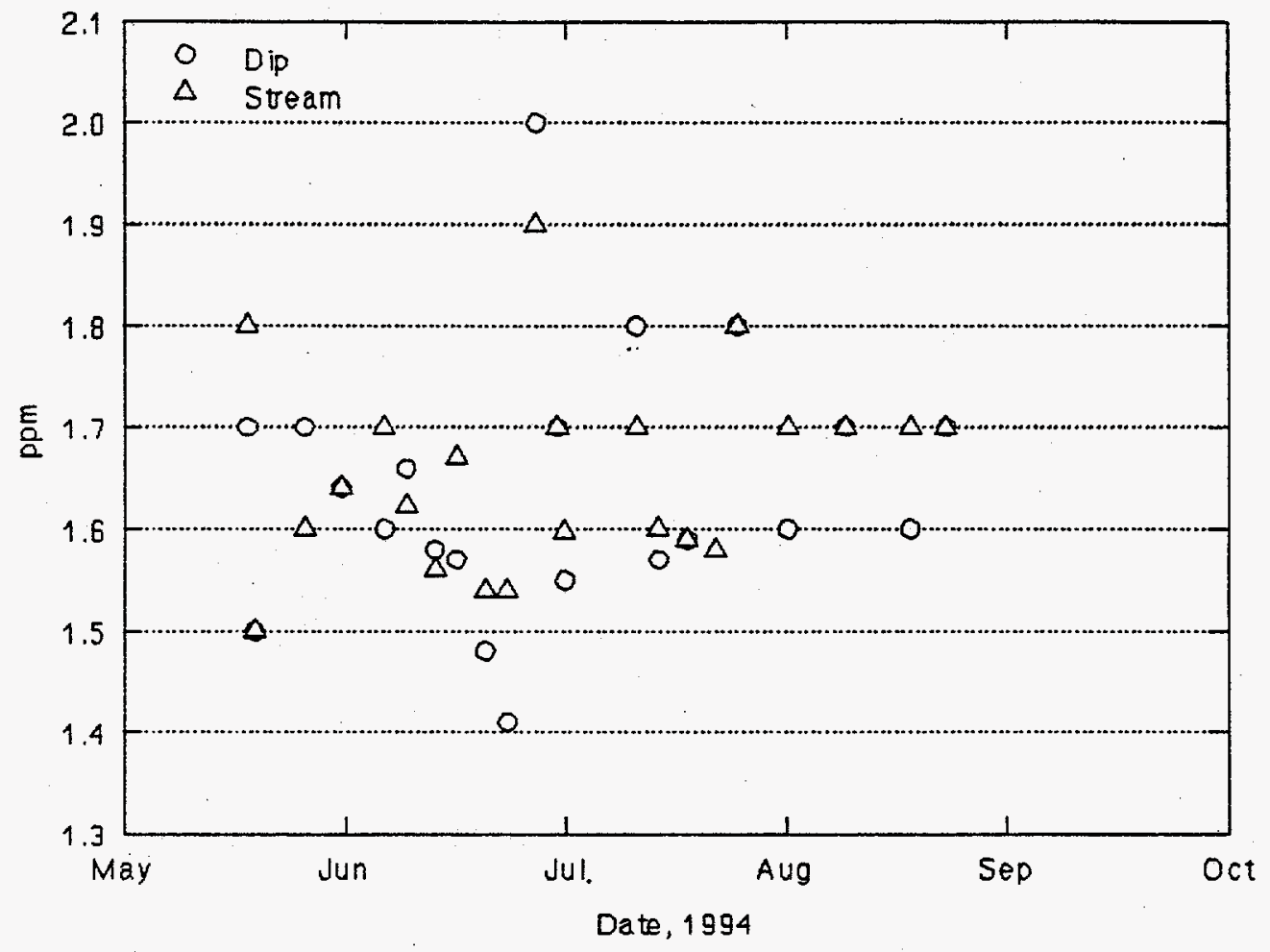

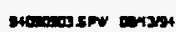

Figure 3.7. Water Chloride Concentration vs. Time 
WHC-SD-SNF-PTR-001, Rev. 0

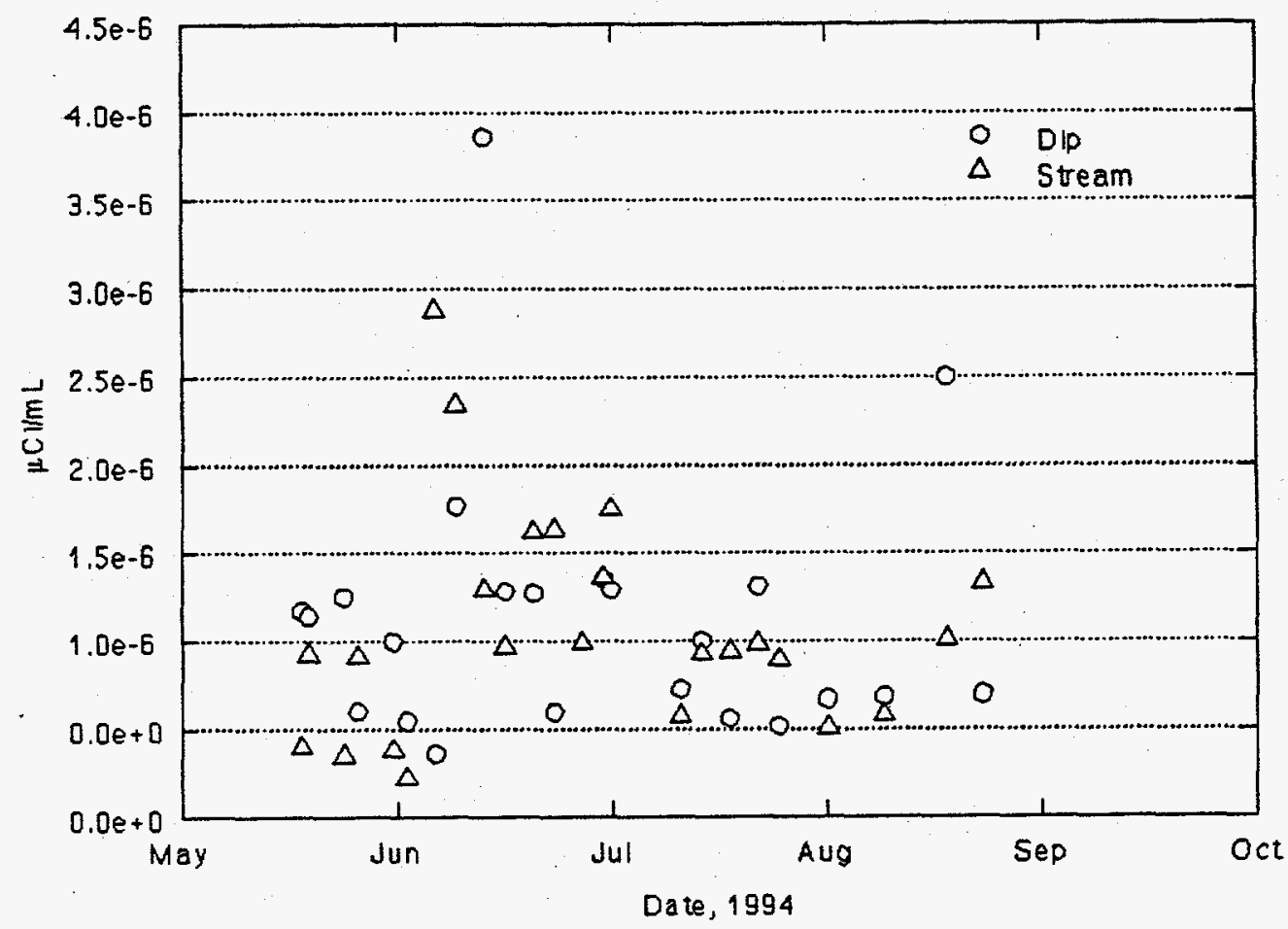

Figure 3.8. Activity of ${ }^{137} \mathrm{Cs}$ in Water vs. Time During the Test 
WHC-SD-SNF-PTR-001; Rev. 0

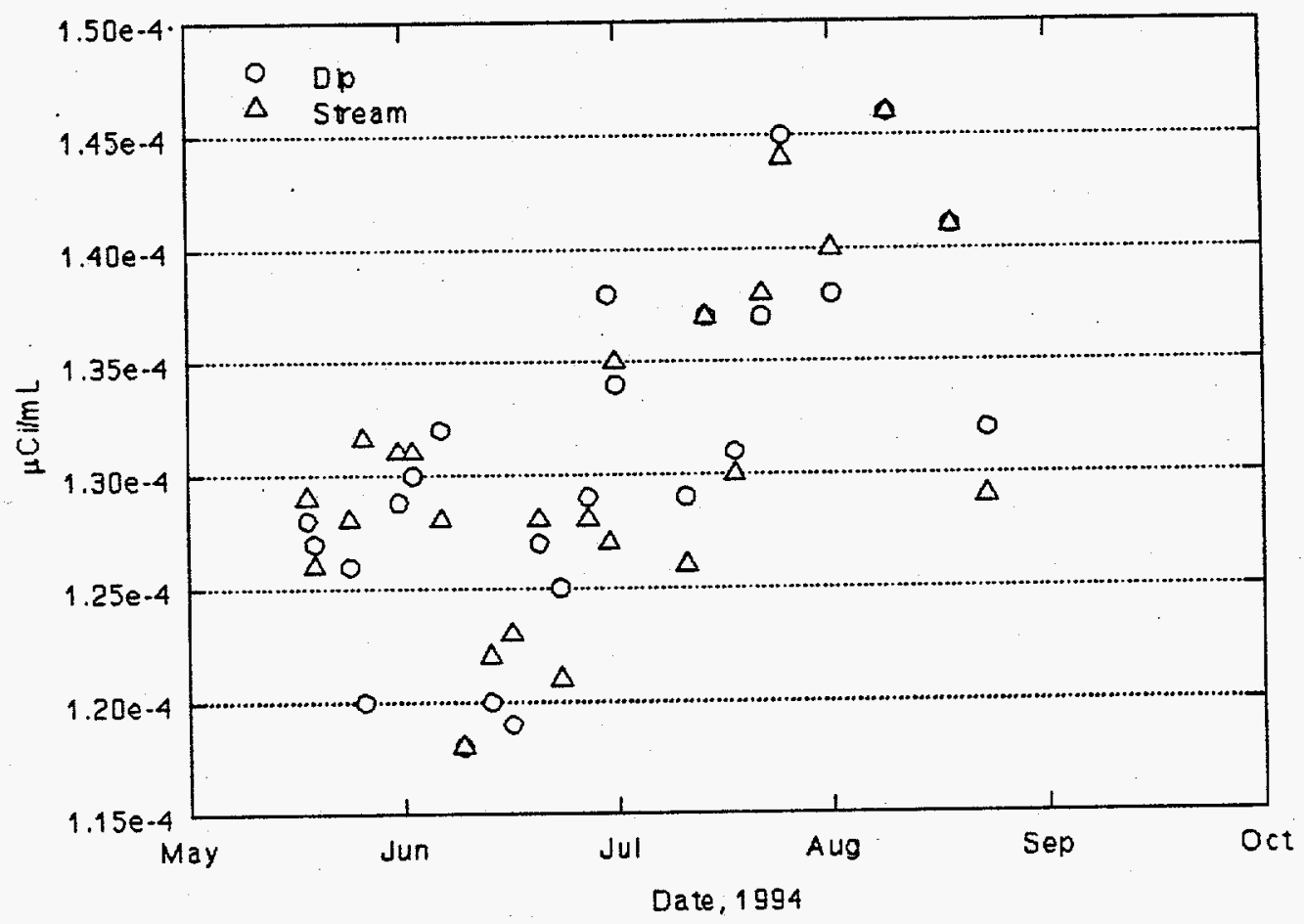

Figure 3.9. Activity of ${ }^{60} \mathrm{Co}$ in Water vs. Time During the Test 
WHC-SD-SNE-PTR-001, Rev. 0

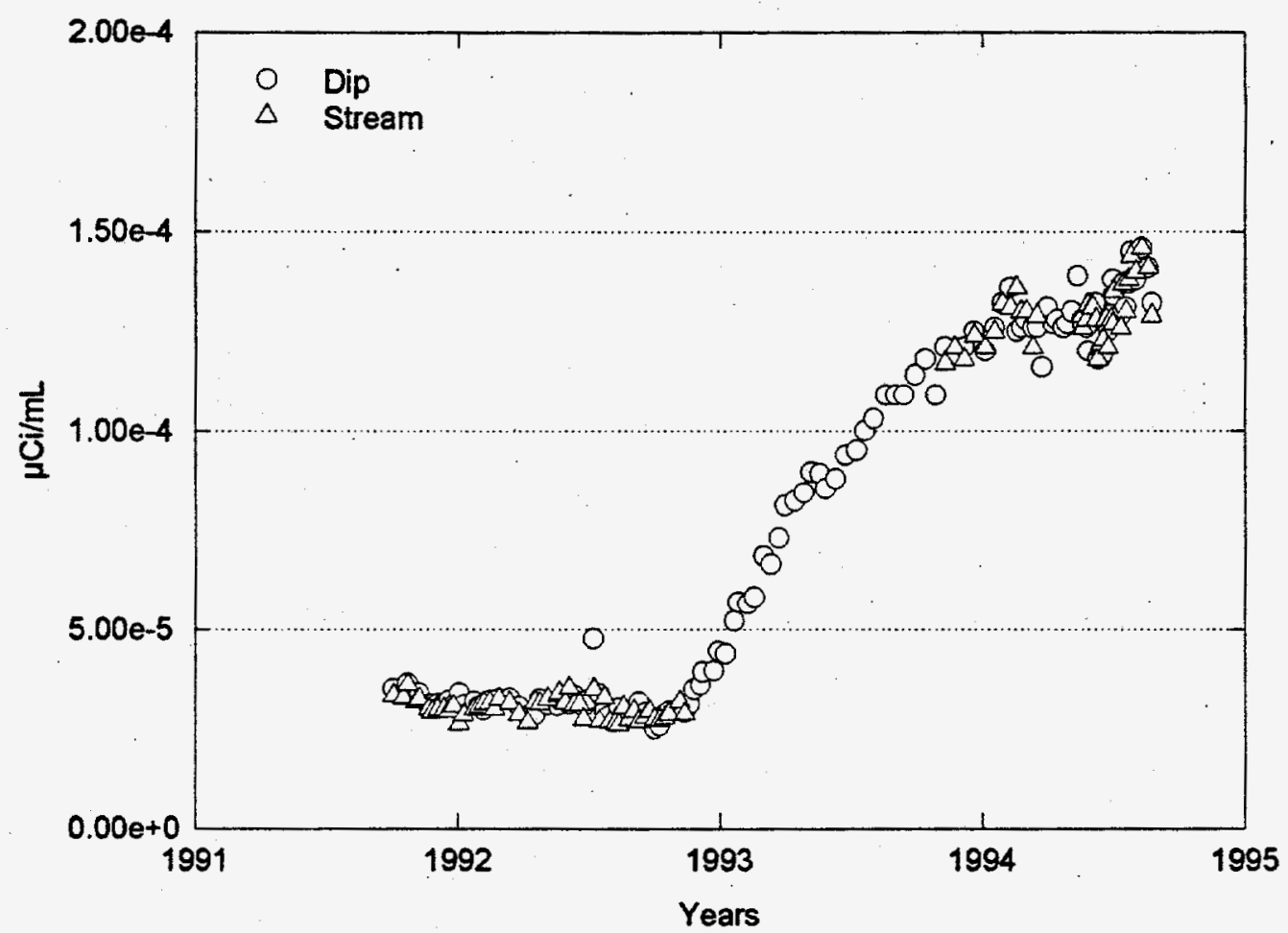

Ma09402.SPW Denter

Figure 3.10. Activity of ${ }^{60} \mathrm{Co}$ in Pool Water vs. Time, from September 1991 to September 1994; Showing the Effect of Pool Cleaning in 1993 
WHC-SD-SNF-PTR-001, ReV. 0

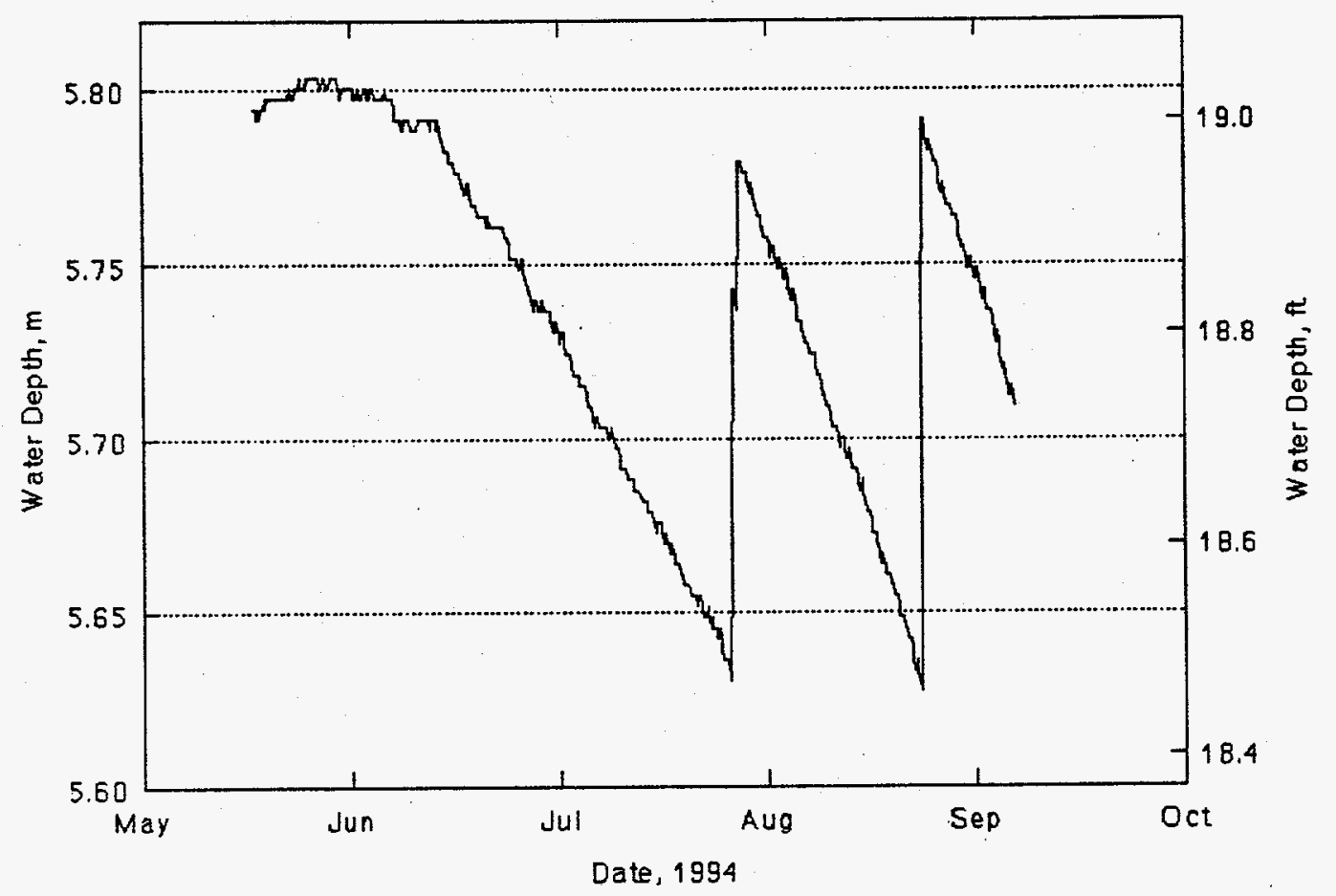

manacteren wases

Figure 3.11. Water Level vs. Time During the Test 


\subsection{Discussion of Results}

The behavior of the pool-water temperatures during the test and the general behavior of the water quality parameters are discussed in this section. The derivations of the thermal models used in pretest temperature predictions are located in the appendix.

\subsection{Water-Temperature Behavior}

When the pool water was chilled, the heat exchangers may have actually been removing ground heat as well as fuel decay heat, since typical ground (earth) temperatures at the depth of the pool bottom are around $10^{\circ} \mathrm{C}\left(50^{\circ} \mathrm{F}\right)$. With the chillers turned off, the two passive heat removal pathways are conduction through the sides and bottom of the pool and evaporation of water from the top. In this mode, the pool resembles a solar-heated natural pond; semiempirical equations for the evaporative heat loss for such ponds were used to estimate that term (see the Appendix). The conduction heat losses from the sides were calculated using nominal values for concrete thermal conductivity and estimates for ambient air and ground temperatures (see also the Appendix). The initial equations used to estimate the equilibrium temperatures that the pool would reach are summarized as follows:

$$
\begin{aligned}
\text { Conduction heat loss }(\mathrm{kW}) & =0.110^{*}(\mathrm{~T}-55) \text { for pool temperature }(\mathrm{T})>55^{\circ} \mathrm{F} \\
& =0.0 \text { if } \mathrm{T}<55
\end{aligned}
$$

when $\mathrm{T}$ is pool temperature in ${ }^{\circ} \mathrm{F}$.

$$
\text { Evaporation heat loss }(\mathrm{kW})=\left[\mathrm{A} /(\mathrm{TK})^{0.5}\right]^{*} \exp \left[-13.11^{*}(373-\mathrm{TK}) / \mathrm{TK}\right]
$$

where $T K=$ pool temperature in Kelvin

$$
\begin{aligned}
& A=\text { constant, determined from measured evaporation rates as determined from } \\
& \text { historical pool refill data. }
\end{aligned}
$$

The constant " $A$ " was given upper and lower bounding values based on the amount of time the PWR fuel-pool operators allowed for pool refills under normal operation. They reported that the pool level fell $0.3 \mathrm{ft}$ every " 2 to 3 months." The dimensions for the pool and the latent heat of evaporation for water result in upper/lower values of " $A$ " of $1745 / 1163 \mathrm{~kW}-\mathrm{K}^{0.5}$. 
WHC-SD-SNF-PTR-001, Rev. 0

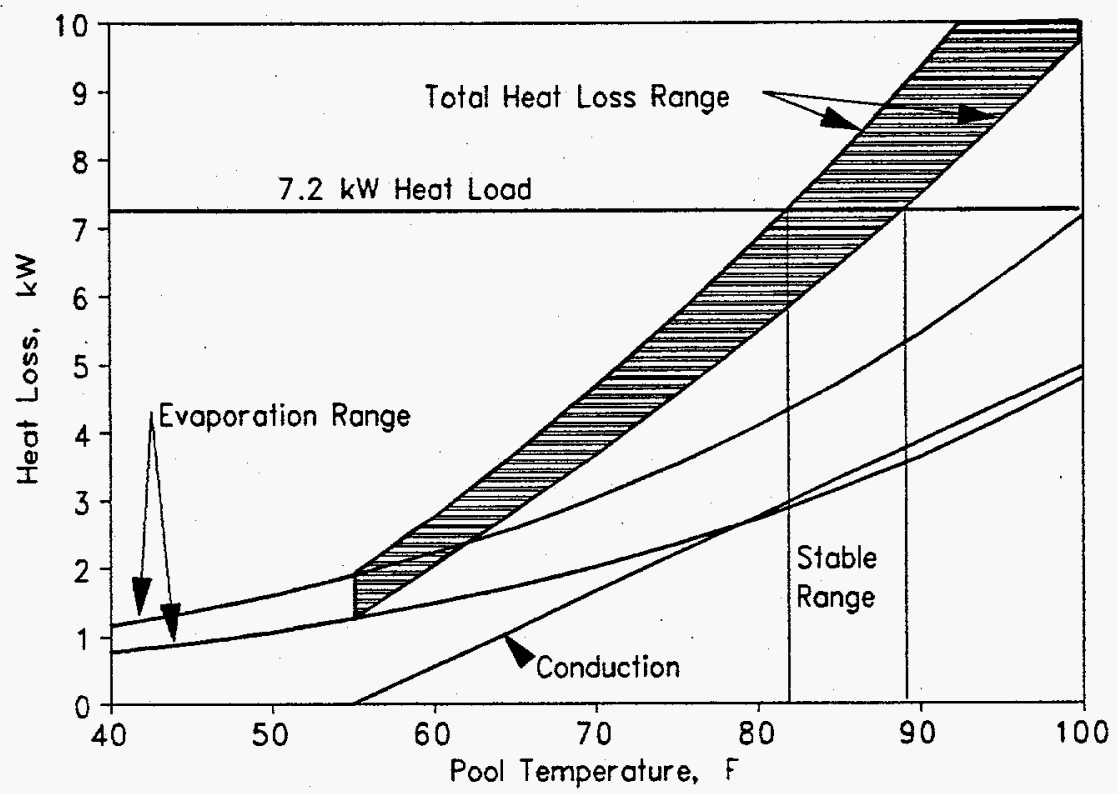

Figure 4.1. Estimated Pool Heat Losses, Heat Loads, and Range for Equilibrium (chiller-off) Water Temperatures 
The estimated range of stabilized temperatures was determined graphically and numerically by matching total heat losses to the assumed $7.2-\mathrm{kW}$ heat load, as shown in Figure 4.1. These heat-loss functions were also used in a numerical solution to the lumpedparameter differential equation for pool-water temperatures to generate the predicted temperatures vs. time. The lumped-parameter equation is simply

$$
\mathrm{dcV} \mathrm{dTK} / \mathrm{dt}=\text { heat load }- \text { heat loss rate }
$$

where

$$
\begin{aligned}
\mathbf{d} & =\text { water density }\left(1.0 \mathrm{~g} / \mathrm{cm}^{3}\right) \\
\mathbf{c} & =\text { water specific heat }(4.186 \text { Joules } / \mathrm{gram} / \mathrm{K}) \\
\mathrm{V} & =\text { water volume }\left(190 \mathrm{~m}^{3}=1.9 \times 10^{8} \mathrm{~cm}^{3}\right) \\
\mathrm{TK} & =\text { pool-water temperature in } \mathrm{K} \\
\mathrm{t} & =\text { time in seconds } \\
\text { heat load } & =7.2 \mathrm{~kW}=7200 \text { watts }
\end{aligned}
$$

heat-loss rate $=$ sum of equations (1) and (2), converted to watts.

The original solution used a heat load of $7.2 \mathrm{~kW}$ (corresponding to the estimated decay heat generation of the fuel assemblies). A revised solution using $7.5 \mathrm{~kW}(7.2+0.3 \mathrm{~kW}$ mechanical pump heat addition), together with the Channel 5 (top-of-fuel rack) water temperature data is shown in Figure 4.2. This revised calculation, which includes summertime ambient air temperatures up to $21^{\circ} \mathrm{C}\left(70^{\circ} \mathrm{F}\right)$, is more consistent with the measured data. Equation (4.1) can also be used to estimate the evaporation rate and, hence, the reduction in pool heating rate. This can then be compared to the measured rate, which is indicated in Figure 3.11. The calculated equilibrium value for this rate is $5.5 \mathrm{~mm} /$ day, which compares well with the $5.75 \mathrm{~mm} /$ day rate derived from the data of Figure 3.11. Because both the equilibrium temperatures and the equilibrium evaporation rate are predicted well by Equations (4.1) through (4.3), it is probable that the estimated partition of heat loss between evaporation rate and conduction is approximately correct, at least at the equilibrium condition. Because of this agreement, the test results provide an approximate consistency check of radionuclide decay heating rate calculations with the ORIGEN2 Code (Morford 1988). 


\subsection{Behavior of Water-Quality Parameters}

The most significant change in water-quality parameters related to the test actually occurred before the test. That was the order-of-magnitude rise and persisting higher values for the ${ }^{60} \mathrm{Co}$ activity, corresponding with the mechanical cleaning of pool surfaces. This occurrence was probably due to the re-disolution (rather than simple resuspension) of cobaltbearing ionic complexes from the fuel element surfaces and from other pool surfaces, caused by other re-disolution/resuspension occurrences related to the cleaning activities. The $\mathrm{pH}$ of the pool shifted slightly upward during the cleaning period (see Figure 4.3); this shift may. have been sufficient to alter the bonding balance (the Zeta potential) of the activity-bearing species on its respective surfaces. Such occurrences have been documented in PWR coolant systems that experience $\mathrm{pH}$ shifts.

During the test, all the measured water-quality parameters remained unchanged. The slight upward shift in the ${ }^{60} \mathrm{Co}$ activity following the movement of the filtration system pump to the pool bottom on August 12,1994, is considered to be possibly related, which may have changed circulation pattern and resuspended activity-bearing contamination on the pool bottom.

Spent-fuel operating experience with GE's Morris pool has shown negligible algae growth under the pool-water limits shown in Table 2.2. Because this experience did not provide direct guidance for algae growth under the pool-water impurity and conductivity level limits shown in Table 2.2 for the PWR Core II pool test, the result of negligible algae growth during this test has provided information needed to support continued operation of the Cell 4 pool at or below these limits without active cooling.

Key factors that are important to prevent algae growth in the PWR Core II pool are to limit algae nutrients by continued maintenance of pool-water impurity and conductivity levels below the limits shown in Table 2.2 and to limit the photon energy below that required to support photosynthesis by continued maintenance of low levels of integrated illumination in the pool.

Experience has shown that adding chemicals in response to algae problems can cause other problems with storage facilities. Chemicals should not be added in response to an indication algae formation without a thorough review of the benefits and potential for new problems. Similarly unreviewed fuel types should not be stored in the PWR Core II fuel pool without further evaluation. 
WHC-SD-SNF-PTR-001, Rev. 0

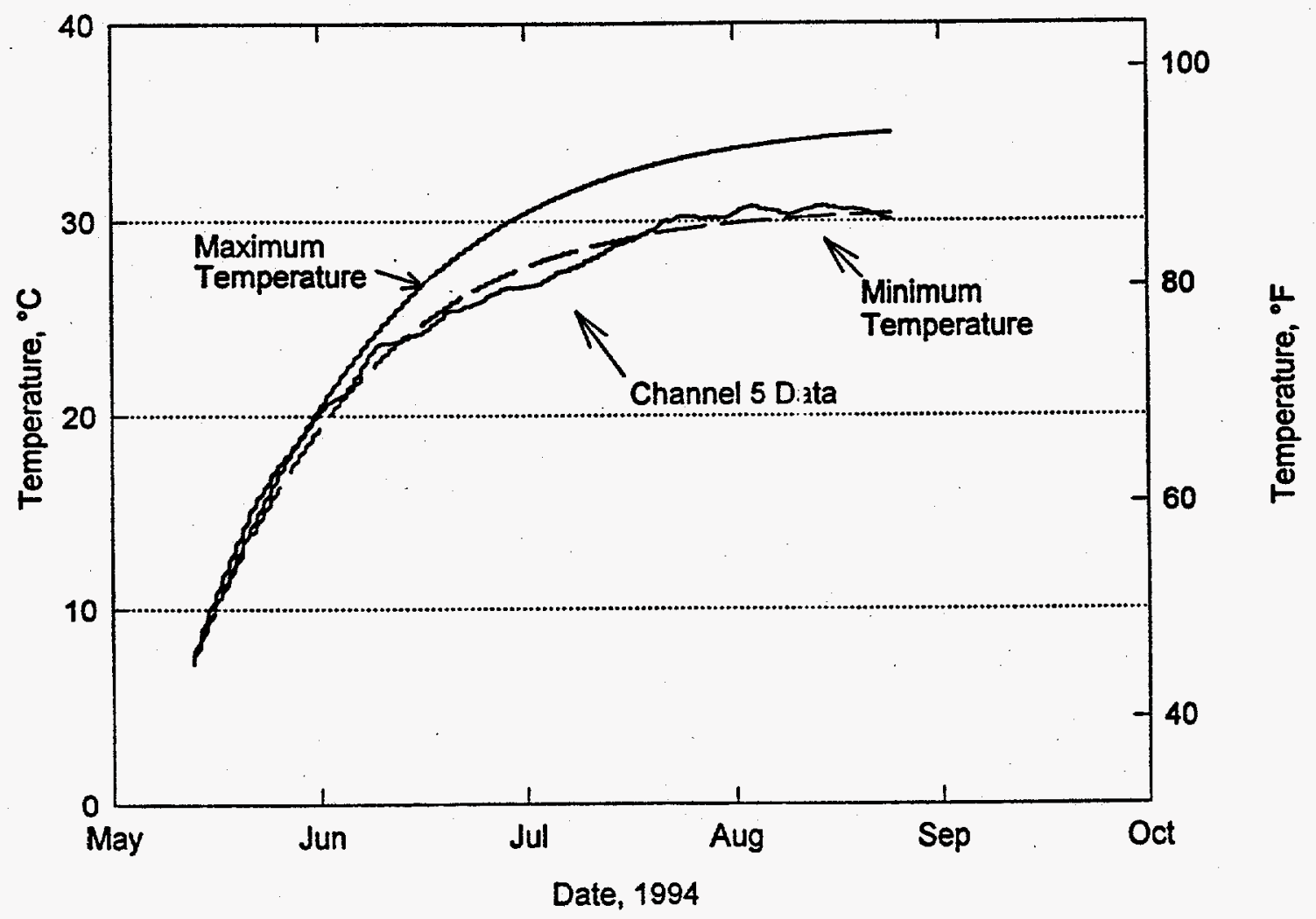

Figure 4.2. Revised Predicted Range for Pool Water Temperatures (with heat load increased to $7.5 \mathrm{~kW}$ ), Compared to Channel 5 Temperatures 
WHC-SD-SNF-PTR-001，Rev. 0

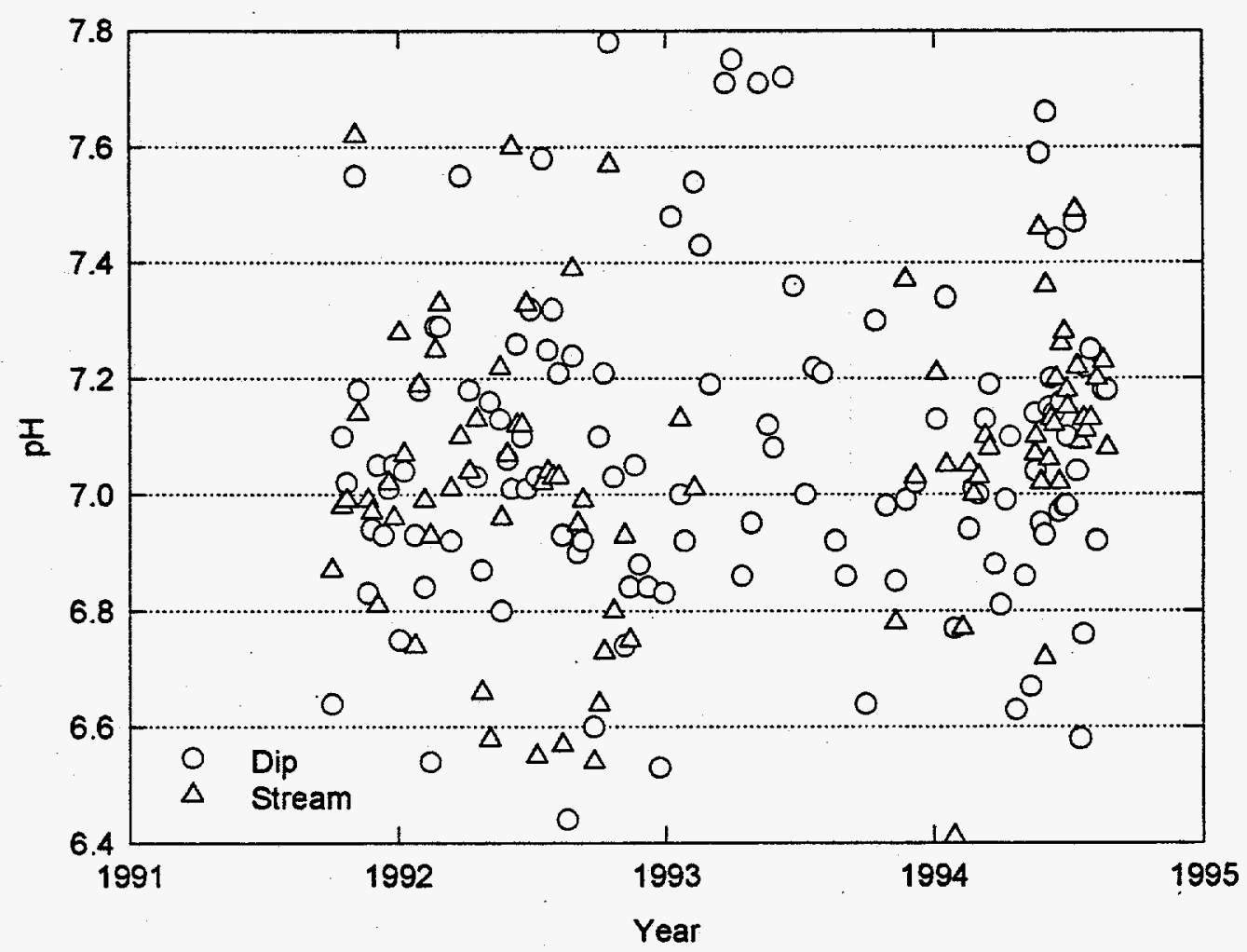

Figure 4.3. The Pool-Water pH vs. Time, from September 1991 to September, 1994 
WHC-SD-SNF-PTR-001, Rev. 0

\subsection{Conclusions and Recommendations}

The key conclusion is that the test confirmed predictions that water temperature will be maintained at a level acceptable for pool storage of commercial spent nuclear fuel without the operation of the chillers. A test of the feasibility of maintaining acceptable storage temperatures with the 72 Shippingport Core II spent blanket fuel assemblies in the PWR Core II fuel storage pool, without active cooling, was performed for approximately 100 days and culminated during an unseasonable hot period in August 1994. To support test feasibility, the peak equilibrium temperatures were estimated by calculating transfer rates from the fuel and equipment heat sources to water evaporation and surrounding pool structure before the test was initiated. The water temperatures measured during the test were within the limits accepted by industry standards and were in good agreement with water temperatures estimated before test initiation. Because of this agreement, the test results also provide an approximate consistency check of radionuclide decay heating rate calculations with the ORIGEN2 Code (Morford 1988).

Relevant experience in commercial spent fuel storage installations at the water conductivity and impurity levels for the PWR Core II fuel pool was not determined for the temperatures expected without active cooling. Experience in commercial spent fuel storage installations indicated that the radionuclides and impurities in the pool water should not increase as a result of pool operation without active cooling. The test results were in agreement with this experience. There were no significant changes in either the pool radionuclides or impurity levels.

Negligible algae growth was observed during the test. These observations support continued operation of the Cell 4 pool at or below the current limits of water conductivity and impurity levels without active cooling.

Key factors that are important to prevent algae growth in the PWR Core II fuel pool are to limit algae nutrients by continued maintenance of pool-water impurity and conductivity levels below the limits shown in Table 2.2 and to limit the photon energy below that required to support photosynthesis by continued maintenance of low levels of integrated illumination in the pool.

The following operating procedures are recommended for pool operations without active cooling:

- Monitor water temperatures to verify storage at less than $38^{\circ} \mathrm{C}\left(100^{\circ} \mathrm{F}\right)$. Statistical scatter and possible bias in thermocouple readings should be accounted for in setting operating limits. 
WHC-SD-SNF-PTR-001, Rev. O

- Sample water quality twice per month to verify that water quality is within limits. In addition, monitor the content of phosphate and nitrate in the pool water; each should be less than 2 ppm. ${ }^{\text {(a) }}$ Water quality superior to current limits would be desirable. Consider improving the current cleanup and water turnover rate relative to the industry standard.

- Monitor the water turbidity and algae growth twice monthly by periodic inspection of a visual reference point in the pool and occasional swiping of pool surfaces.

- Do not add chemicals in response to an indication of algae formation without a thorough review of the benefits and potential for new problems. Do not store additional fuel in the pool without further evaluation.

The water cooling capability is no longer needed for the PWR Core II fuel-storage pool as long as no additional heat loads or additional fuel are added to the pool, the water quality is maintained or improved, and the water quality, radioisotope concentration, and temperatures continue to be monitored. A change to continuous operation of the recirculating pump would be a significant added heat load.

(a) The basis for this recommendation is that phosphates and nitrates provide nutrients for algae. General Electric Company's experience at Morris shows that maintenance of low nutrient levels, such as those recommended here, inhibit algae growth even in lighted and heated pool conditions. 


\subsection{References}

American Nuclear Society. 1988. Design Criteria for an Independent Spent Fuel Storage Installation (Water Pool Type). ANSI/ANS-57.7, American Nuclear Society, LaGrange Park, Illinois.

Hanson, G. L., and R. R. Jackson. 1978. Safety Assessment Document - PWR Core 2 Project. RHO-CD-356, Rockwell Hanford Company, Richland, Washington.

Johnson, A. B., Jr. 1977. Behavior of Spent Nuclear Fuel in Water Pool Storage. BNWL2256, Pacific Northwest Laboratory, Richland, Washington.

Morford, R. J., L. L. Carter, R. A. Schwarz, W. P. Stinson, and W. L. Bunch. 1988. Radiation Source in the Shippingport Pressure Vessel Package. WHC-SP-0408, Westinghouse Hanford Company, Richland, Washington. 
WHC-SD-SNF-PTR-001, Rev. ?

6.2 
WHC-SD-SNF-PTR-001, Rev. 0

Appendix

Pool-Heating Calculation Worksheets

A. 1 
WHC-SD-SNF-PTR-OUI, Rev. 0

A. $i 1$ 
WHC-SD-SNF-PTR-001, ReV. 0

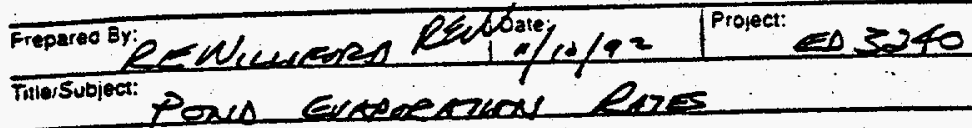

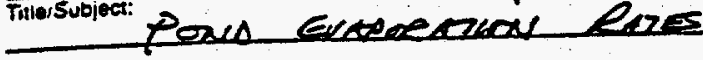

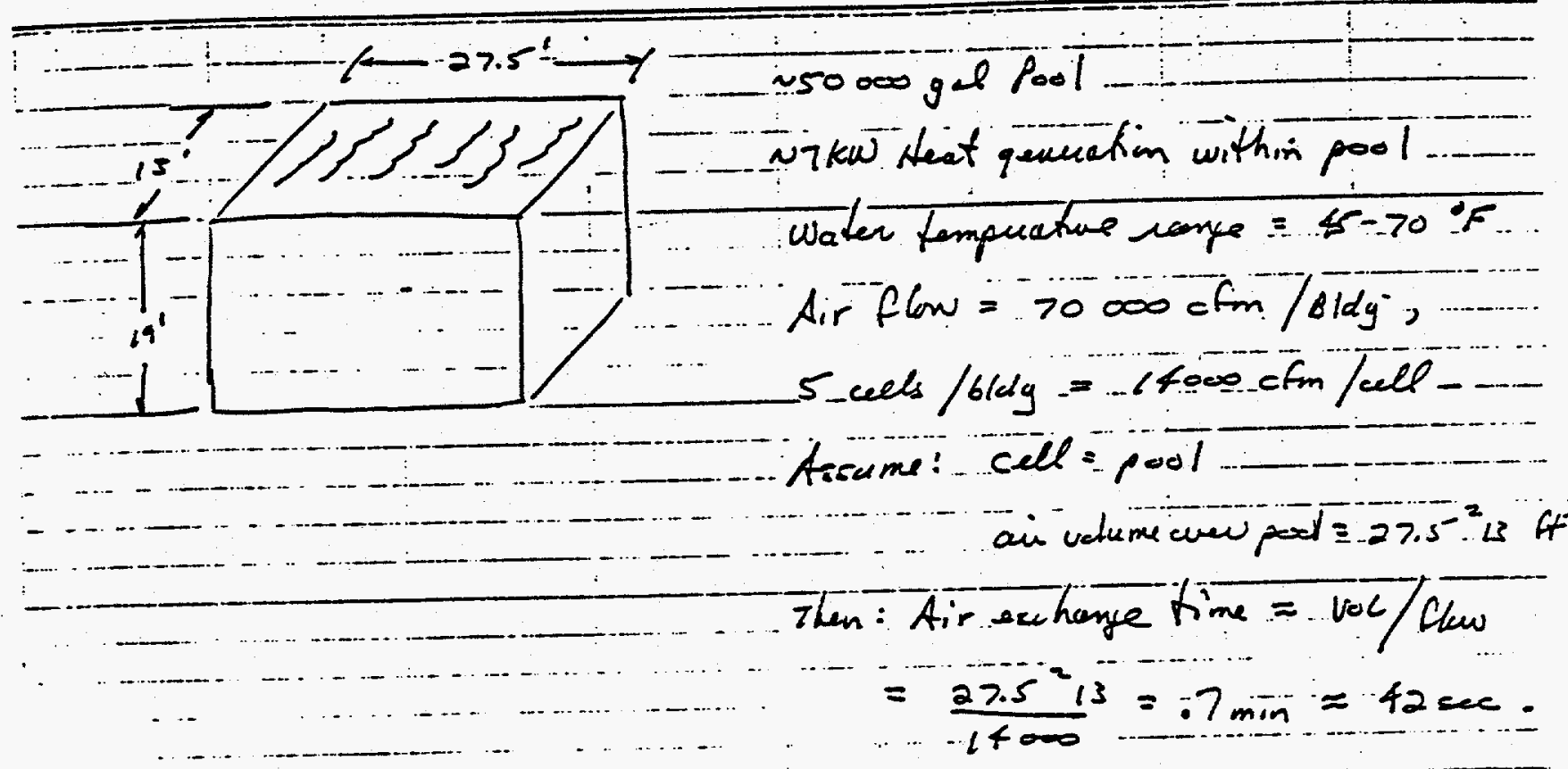

\section{Rough Estimetes}

1. T.102 - D. shaw Sutro to Colbid and Surface Chemutry Buterumeths publ .. (985.

Annual ber of watew feom hot ceunty lates and

recenvirs due to ivapration is asually elait

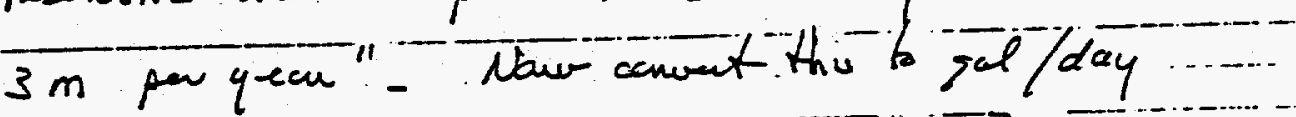

for the abive podl: ... lgal $=3785.7 \mathrm{~cm}^{3}$

$-\ldots$

Pol cuea $=332,128.37 \mathrm{~cm}^{2}$

Igal an poil surbce has depthd $\frac{37 \varepsilon 5.4}{32128}=.0114 \mathrm{~cm}$

So, $3 \mathrm{~m} / \mathrm{gr}_{\mathrm{r}} \rightarrow \frac{30 \mathrm{~cm} / \mathrm{gr}}{.0114 \mathrm{~cm} / \mathrm{gd}}=-2632 \mathrm{gal} / \mathrm{yr}=7.21 \mathrm{gal} / \mathrm{day}$ IR: Aporox $14.7 \mathrm{gal} / \mathrm{Lag}$ Summie

- ...... 0 gal/das umintu 


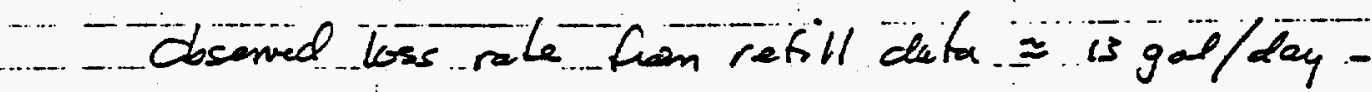

.... So the pool is ampenable to a pand in summer-

2. Py 62 Aw thams, physical cheimising of Surfacis, wiley Publo iago from-gos kineti theing, number fondes striking $l \mathrm{~cm}^{2}-g$ surtace pew acend B . $Z=P / \sqrt{2 \pi m R T} \ldots$. For uoper satruated with inpect to liguid watev at coom temperature $z \approx 0.02-\mathrm{mol} / \mathrm{cm}^{2} \mathrm{sec} \approx 1.2 \times 10^{22}$ moleciules $/ \mathrm{cm}^{2} \mathrm{sec} \div$ it equibioniom, evoporation sate = condens ation iate, defering by a frector $\alpha$ (evopwathon coetticuent), which varies by 3 ardus of magnitucle $\left(10^{-3}\right.$ to 1.0$)$ f seepy 152 telams m). Assuming saturated cin abcue pool, then at $70^{\circ} F$, evopiration.

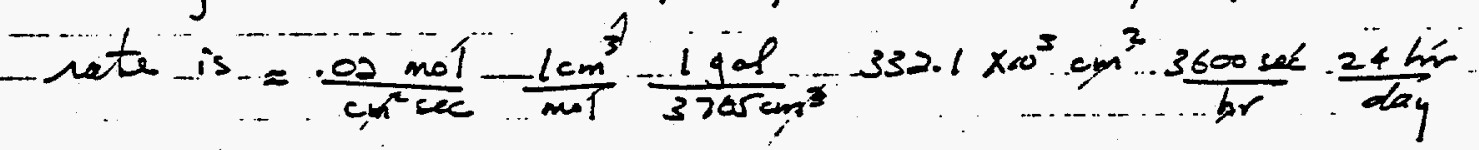

$$
=151,629 \mathrm{jal} / \mathrm{day}
$$

This lenge value equires an enoporation oceficient $\alpha=10^{-4}$

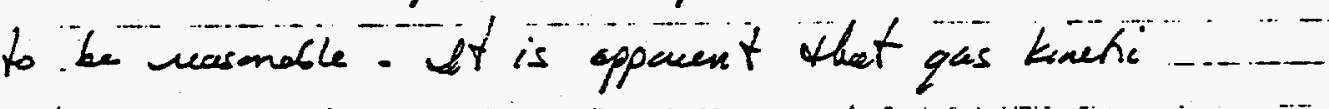
theary applied to this pactiem can be subjet to same serious uncectainties - It is therefore advisadle to work with rietative cates to study the temperative dependerce of pool eispration. 
Relative Rates \& Evaparation

Fran IN. - Levixe , Physical chemiity, Mc Graw- thil 1988 , - pofe tist, the iale of escupe (qus effusion vate).

is $\frac{d N}{d t}=-\frac{P N_{t} \text { Anow }}{\sqrt{2 \pi M T}}$.... whe

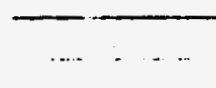

Anole = avea g "hole" in surface fim thengh which $N_{k}=$ moleculs pass

$p=$ coper pressure abcue ligieid (ejullibrium)

Now Com pare $200-202$ g buine, the vopor pressure

is quien by the Clacierines Clapeyton Egn

$d \ln P=\frac{\Delta \bar{A}}{R T^{2}} \quad$ cseuming $\Delta \bar{A}$ does not chaye mach with Tempriature.

this last assumption means that we dan' want to get too

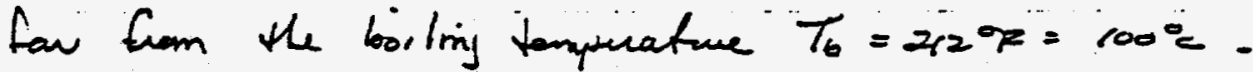
with $\Delta$ itue $=60.66^{-} \mathrm{kJ} / \mathrm{mol}$ for watu (pqe zeo), we have $\frac{P}{\rho^{2}}=\exp \left[-\frac{\ddot{\Delta} \bar{R}}{R} \frac{T_{b}-T}{T_{L} T}\right]$ and $\rho^{*}=1 \mathrm{~atm}$.

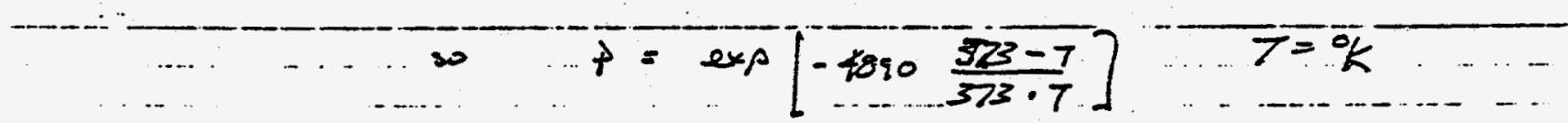

Now: $\left.\frac{d N}{d t}\right|_{T} \equiv E_{T}=\operatorname{constant} \cdot \frac{\exp \left[-\frac{4890}{2}\left[\frac{373-7}{373.7}\right]\right]}{\sqrt{T}}$ 


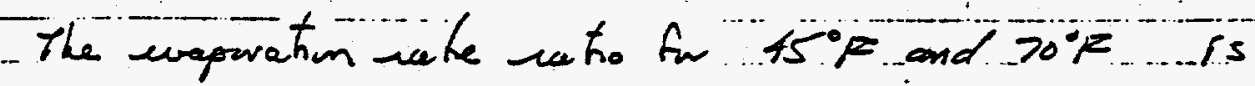

$$
\begin{aligned}
\frac{E_{70}}{E_{45}}- & =-\exp \left[-489 \frac{(373-294)}{373 \cdot 294}\right] / \exp \left[-4890-\frac{(373-280)}{373 \cdot 280}\right]-x \cdot \sqrt{\frac{280}{294}} \\
& =\frac{\exp [-3.5227]}{\exp [-4.3544]} \cdot \frac{1.9524}{=}=2.2971 \cdot .9759=2.24
\end{aligned}
$$

For t5 $\mathrm{F}$ and $10^{\circ}, \mathrm{p}$, we have

$$
\frac{E_{10}}{E_{45}}=\frac{.0733}{.0129} .9489=5.41
$$

Refriement

Since were one signifantly depacted fin the

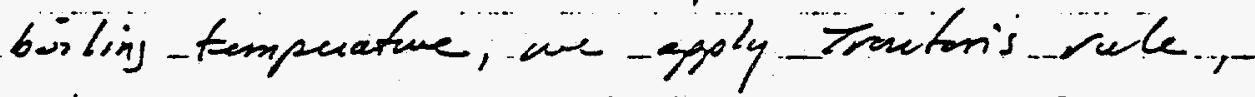
which is especrelly impontant for polar laguids such as watu

$$
\Delta S_{\text {oup } \text { In.6. }}=4.5 R+R \ln \left(T_{n} b_{p}\right)
$$

whe nbe = namel boilin point $=3730 \mathrm{~K}$, so

$$
\Delta \text { Sogp,abp }_{p}=4.5(8314)+8.314 \ln (373)
$$

$\ldots=86.64 \mathrm{~J} / \mathrm{mol}{ }^{\circ} \mathrm{K}$

Now for the clausius clapegron-quation

$\frac{d P}{d T}=\frac{\Delta S}{\Delta \bar{V}}=\frac{\Delta S}{\bar{V}^{2 s}}$, and $V g^{a}=\frac{R T}{P}$ 
Battelle

$$
\text { WHC-SD-SNF-PTR-001， Rev. } 0
$$

Page 5 : 6

- Pacific Northwest Laborarorin

ENGINEERING WORKSHEET

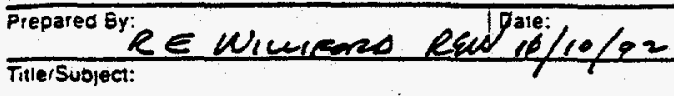

$$
\begin{aligned}
& \frac{d P}{d T}=\frac{\Delta s}{R T} P-\text { so }-\frac{d P}{P}=\frac{\Delta s}{R} \frac{d T}{T}
\end{aligned}
$$

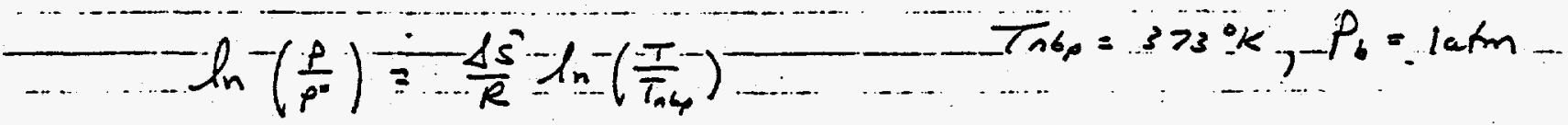

$$
\begin{aligned}
& \begin{array}{l}
-\frac{d P}{d T}=\frac{\Delta s}{R T} P-\text { so } \\
\ln \left(\frac{P}{P^{*}}\right) \frac{\Delta s}{R} \ln -\left(\frac{T}{T_{n} b}\right)
\end{array} \\
& p=\left(\frac{\frac{T}{T}}{T_{n b p}}\right)^{10.42} \\
& \frac{E_{70}}{E_{45}}=\left(\frac{294}{200}\right)^{00.42} \sqrt{\frac{280}{224}}=1.61 \\
& \frac{E_{00}}{E_{15}}=\left(\frac{311}{280}\right)^{10.92}(.95)=2.8 \overline{2}
\end{aligned}
$$

These numbers are sulstantraily-betar precious estimates, so -.. do a final check against data. Page 202 of levine contains a plat that ques $\frac{\Delta H_{r}}{R}=5122$, as opposed to the 4820 - - used before - with this revue, we fer

$$
\begin{aligned}
\frac{E_{70}}{E_{45}}=\frac{.0249}{.0104}(.97) & =2.32 \\
\frac{E_{000}}{E_{5}} & =\frac{.0617}{(.05)}=5.91
\end{aligned}
$$

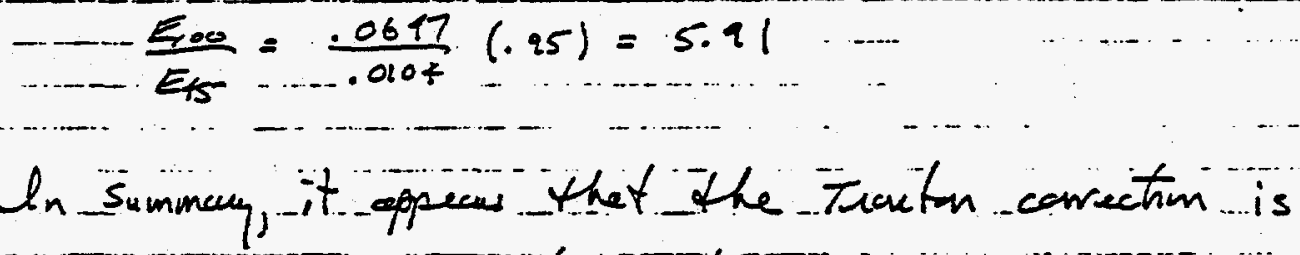
erroneous, and euporetem rates will vary by up to a factor of abut six es the pool sate temperature rises to $100^{\circ} \mathrm{F}$. Note that this analysis ignores the nen-equilioncion effect of cir circulation aloe the pool, and the air tempuatue/humidity factors - The facts DoE int Ruenieno wa

S4.9007+i:4a1 63)

A.5 
WHC-SD-SNF-PTR-001, Rev. 0

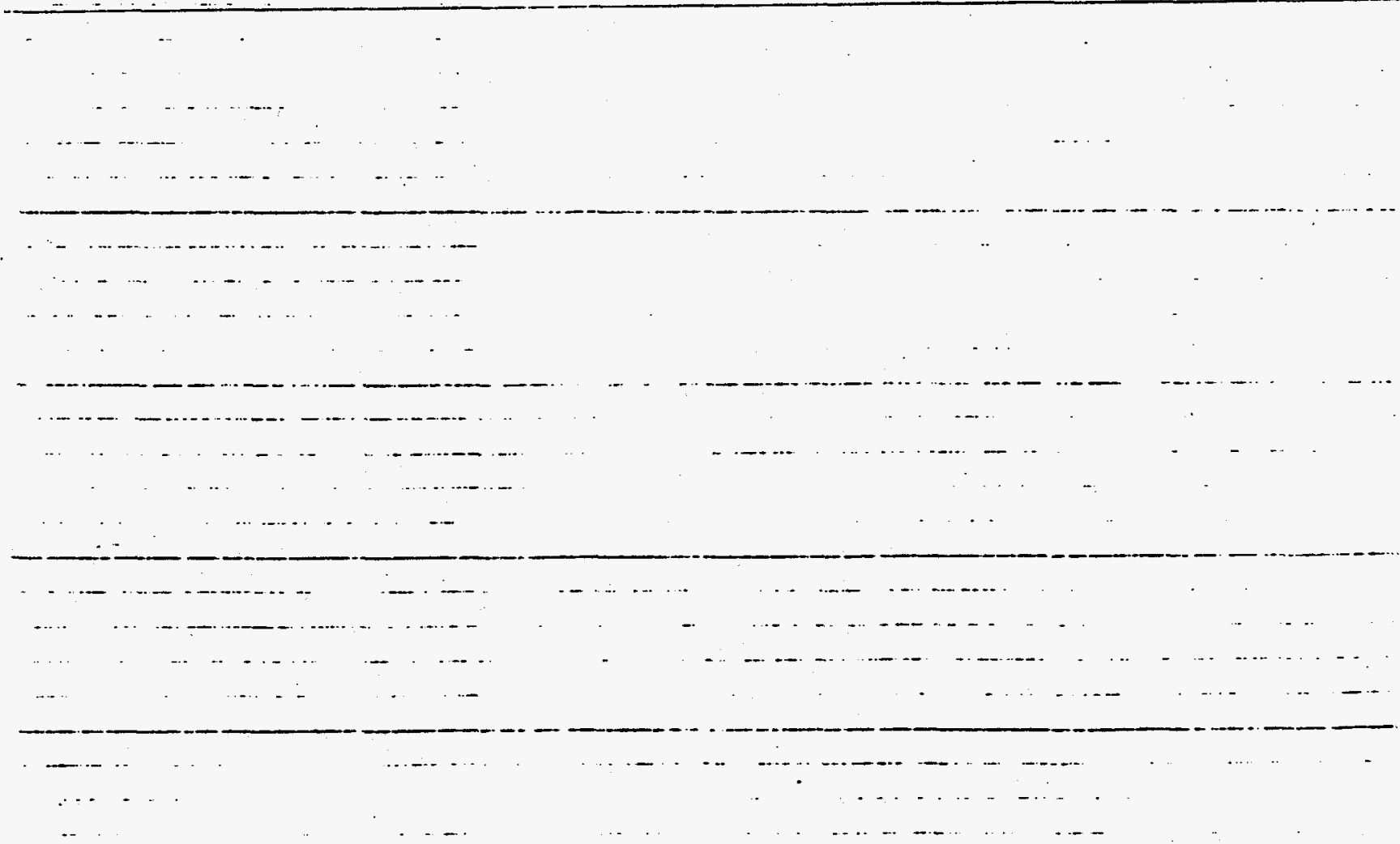




$$
\text { WHC-SD-SNF-PTR-001， Rev. } 0
$$

AHach 2

Battelle

Pacfic Nontmmest Laborstorves

ENGINEERING WORKSHEET

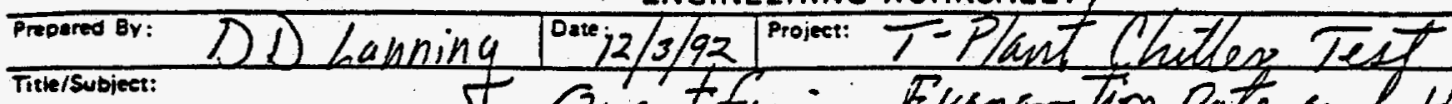

Rate (Range) Qr.
Data L Assamptions

1. "Everis Two th three minth" apiencling to T-plant celly

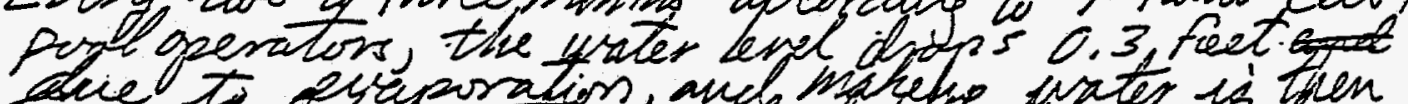

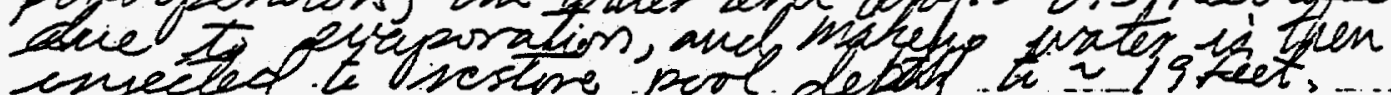

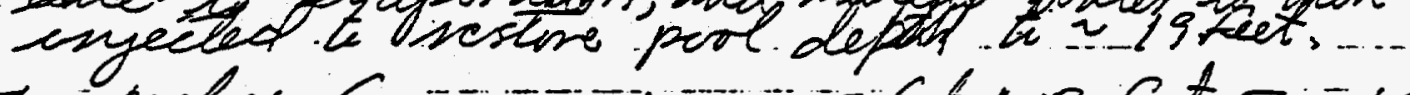

2. The pers surface area is 27.5 fet $\times 13$ feet, - Temp $=45^{\circ} \mathrm{F}$

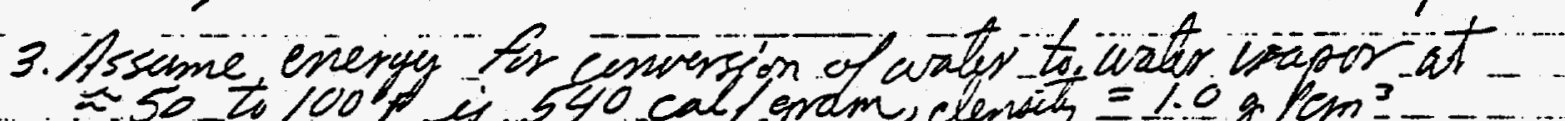

…… 050 to 100 is 540 cal/,gram, clemsisy $\equiv 1.0 \mathrm{~g} / \mathrm{cm}^{3}$

I- Quantifiatuon of Evaporitios Rate

* $2.48 \mathrm{gal} / \mathrm{cu} . \mathrm{ft}_{\mathrm{t}}=9.0 \mathrm{to} \mathrm{B} .5 \mathrm{gal} / \mathrm{day}$

It - Heat Loss. 'ks. Pool Water Tempenture

9.0 to 13.5 galday * $3785 \mathrm{~cm}^{3}-\bar{x} 7.0 .97 \mathrm{~cm}^{3} * 540 \mathrm{cal} * 4.186 \mathrm{~J}$

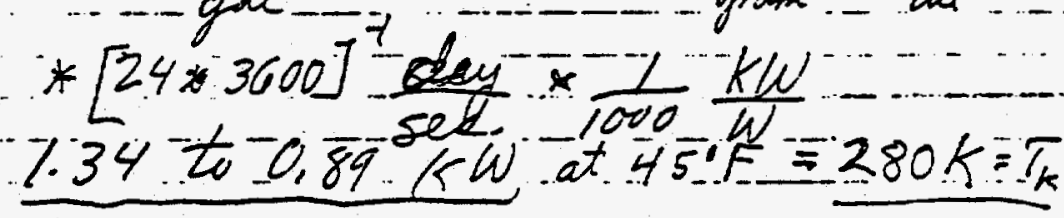

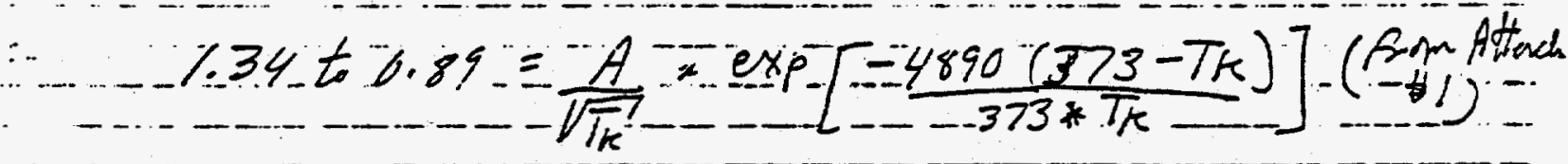

$$
\begin{aligned}
& =0.00768 * A \\
& -A=1163 \text { to } 1745 \text { for_hest loss in KW }
\end{aligned}
$$

A.7 
Battelle

WHC-SD-SNF-PTR-001, Rev. 0

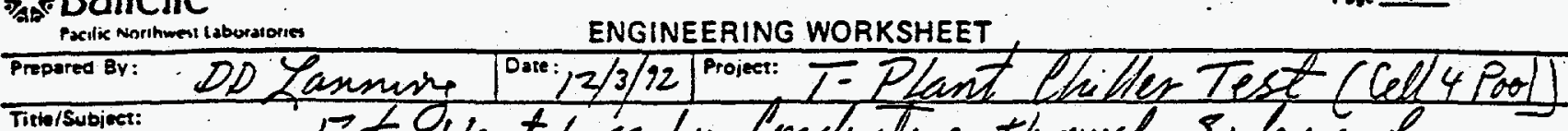

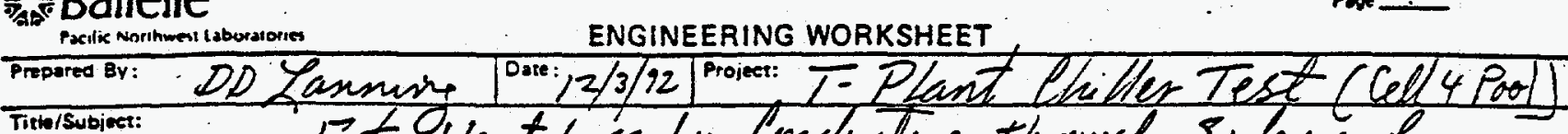

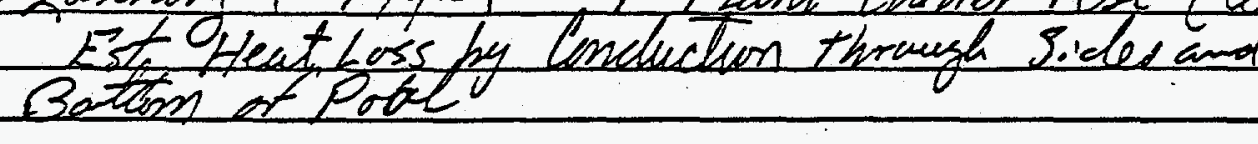

Data/Assemothins

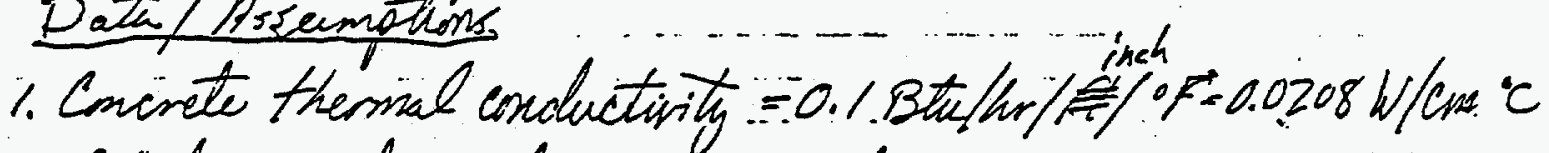

2. White ceinent cind = same as abore

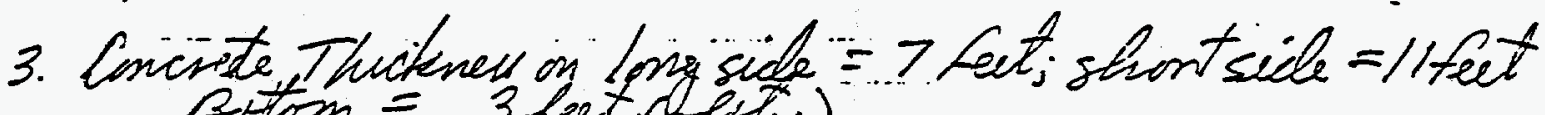

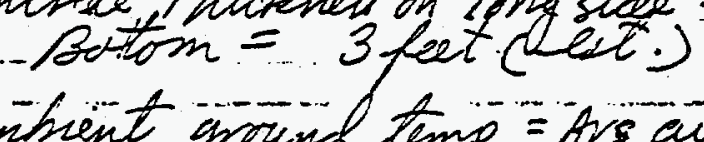

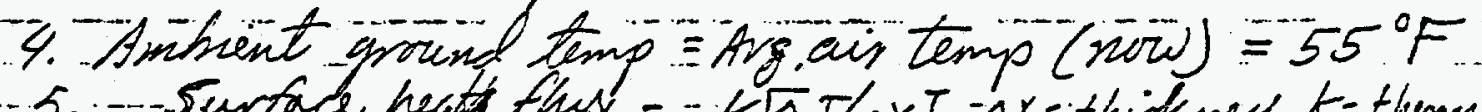

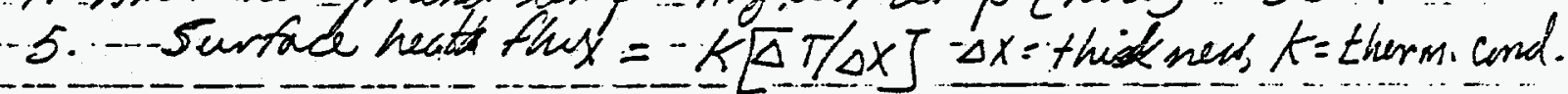

I. Suritace Areass

(2) Sides Lorig $=27.5+19 \div * 144 * 2: 54^{2} \times 2=9.7 \times 10^{6} \mathrm{~cm}^{2}$

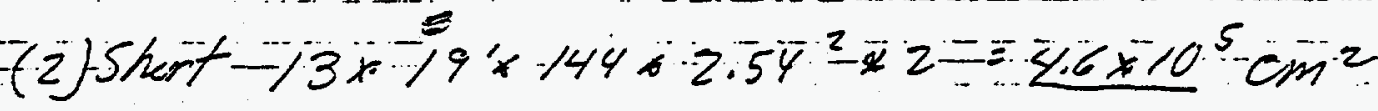

Bottom = $13 \times 27.5 \times 144+2.54^{2}=3.3 \times 10^{5} \mathrm{~cm}^{2}$

II Heat Flow per $10^{\circ} \mathrm{F}$ Ahorice Ambient

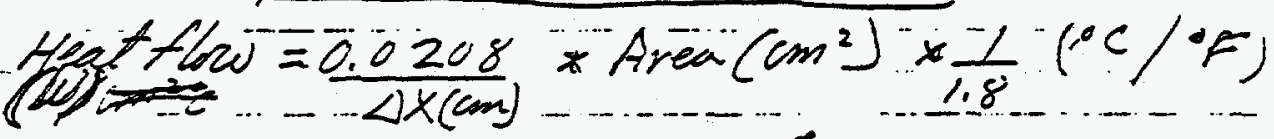

$$
\begin{aligned}
& =\frac{0.0208}{1.8}\left[\frac{9.7 \times 70^{6}}{7+12+2.54}+\frac{96 \times 10^{5}}{-1 / 12 \times 2 \times 2.54}+\frac{3.3 \times 10^{5}}{3 \times 12 \times 2.54}\right] \\
& =-10,208\left[0,45 \times 10^{4}+0,14 \times 10^{4}+0,36 \times 10^{4}\right] \\
& \begin{aligned}
=0.00 \mathrm{~W} /: \mathrm{F} \\
=
\end{aligned}
\end{aligned}
$$

So Heat loss $(k \omega)=0.110 *\left(T_{\text {poor }}=55\right), T_{\text {pood }}$ in ${ }^{\circ} \mathrm{F}$

A. 8 
WHC-SD-SNF-PTR-001, Rev. 0 Vifiudity

Battelle ENGINEERING WORKSHEET

pape 1 ot

Pxinc Noritwest lobormories

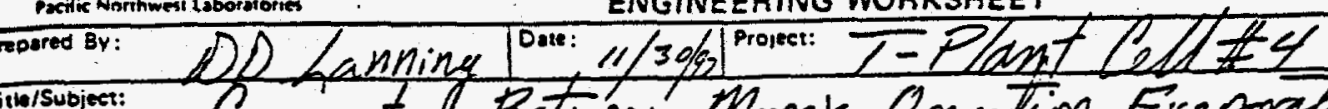

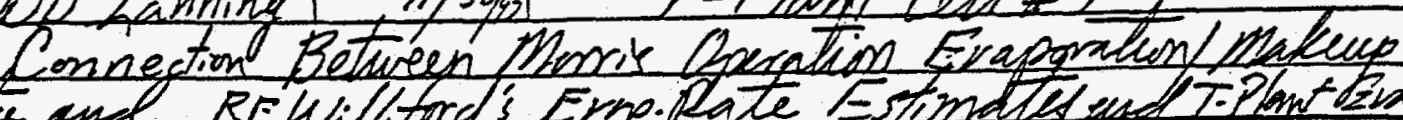

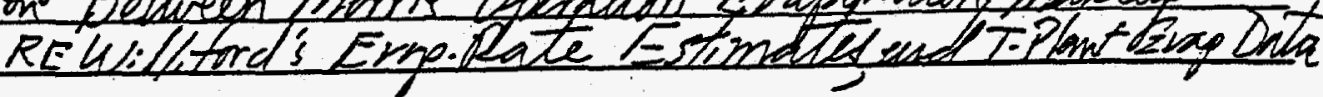

DatalAssumphotons:

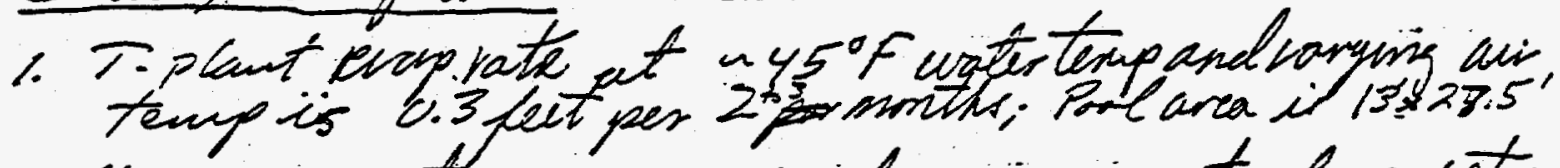

2 Mmir crap rate id 100,000 gal per years at estarg water

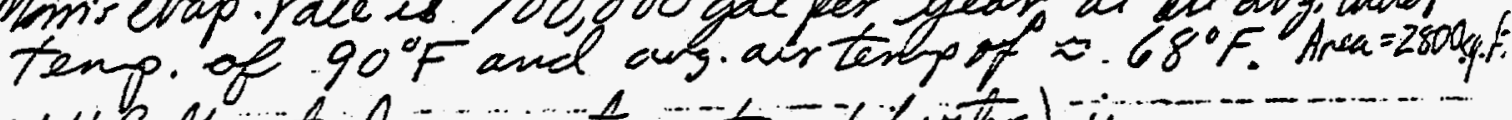

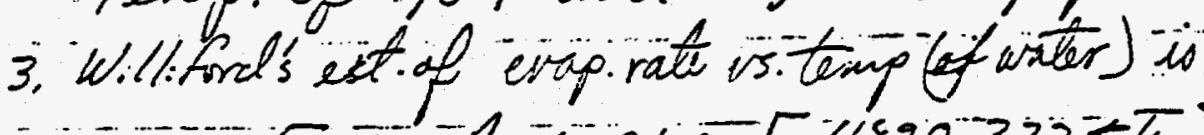

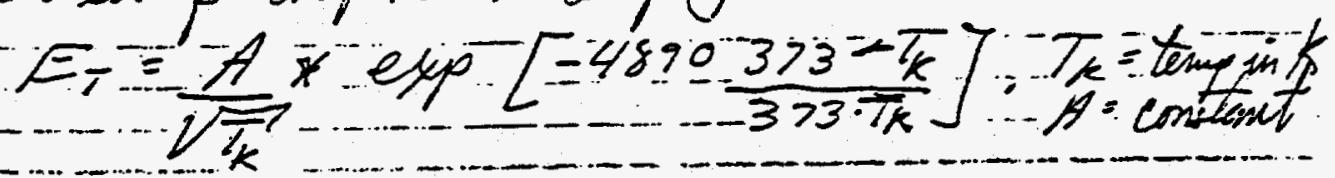

T-Plant Erap. Rate

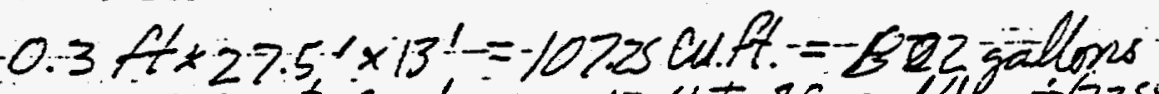

$$
\begin{aligned}
& \div 60 \text { to } 90 \text { days }=13.4 \text { to } 8.9 \mathrm{gal} / \mathrm{day}, \div(27.5 \mathrm{~s} \cdot 3)=0.03 \text { to } 0.025 \\
& \text { gal/sg. Ft/day }
\end{aligned}
$$

Solving for " $h^{\prime}$ " $. T_{k}=280$

$$
0.037 \text { to } 0.025=0.000768 \times A ; A=48 \text { t } 32 \text { gatgetlear }
$$

Nowis Evap Rate-

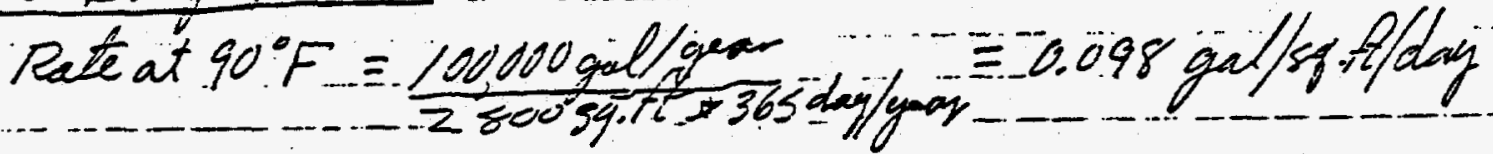

$$
\begin{aligned}
& \text { Solting for " } A \text { " } T_{k}=305 \text {. }
\end{aligned}
$$

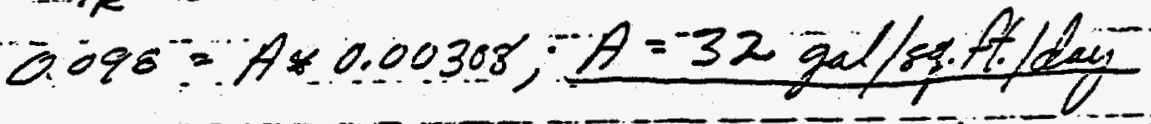

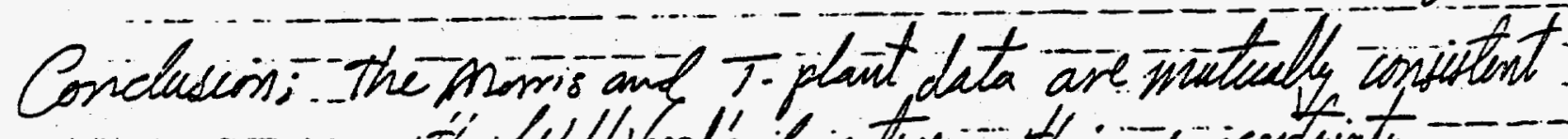

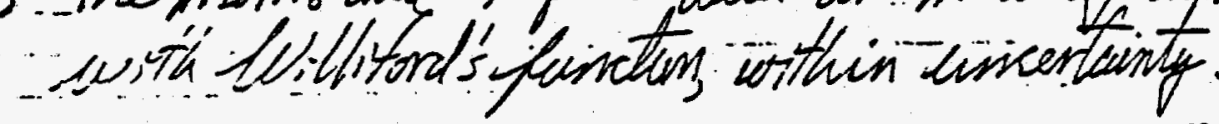

A.9 


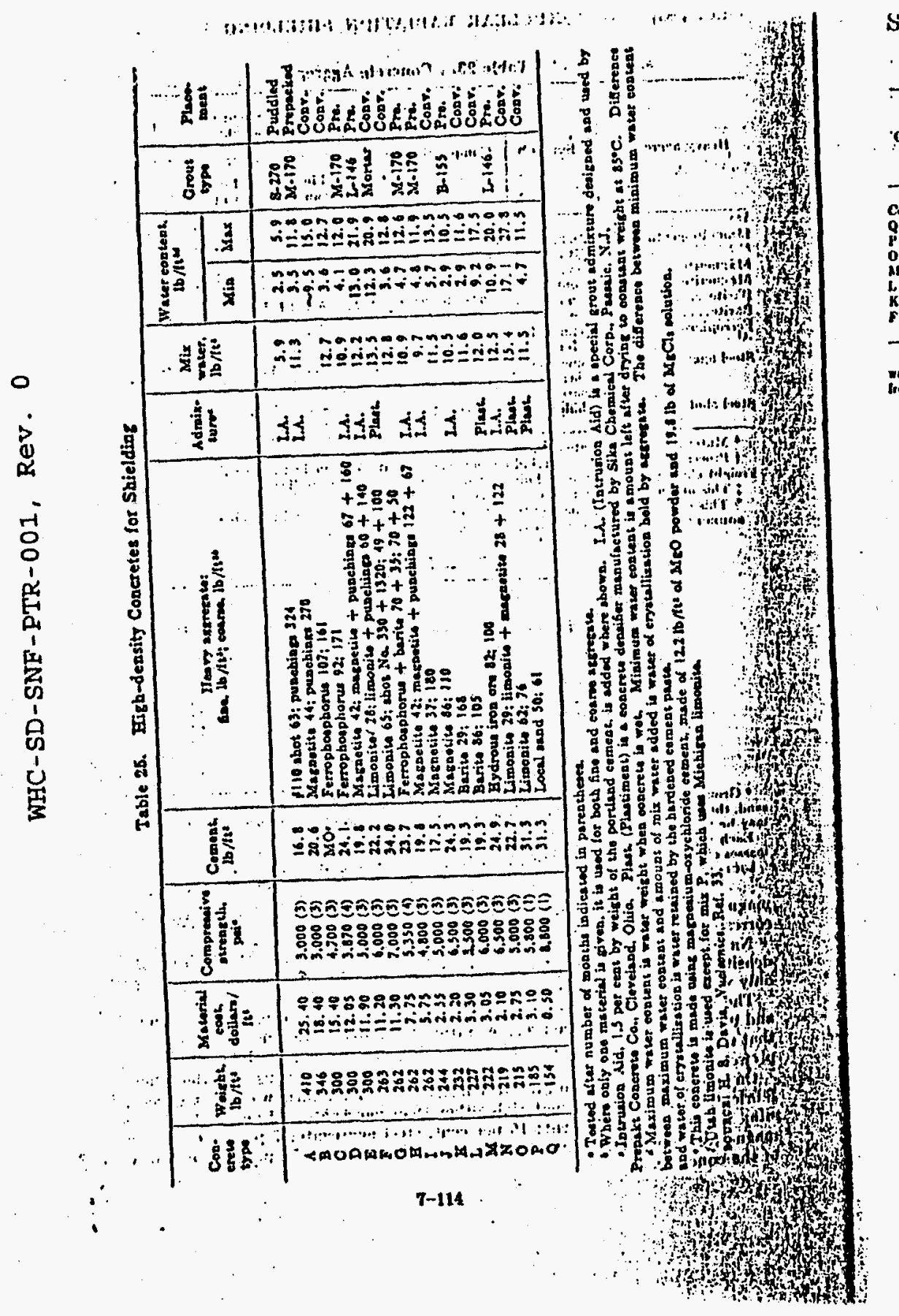

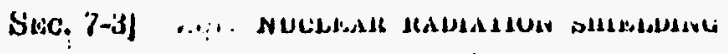

- ...

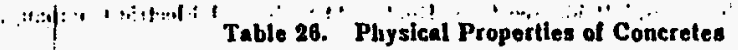

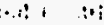

\begin{tabular}{|c|c|c|c|c|c|c|c|c|c|c|c|}
\hline & is/stai & $(13489 / y 6$ & 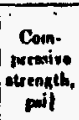 & 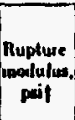 & 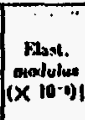 & 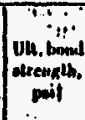 & $\begin{array}{l}1 \\
\text { shorilut. } \\
\text { aras } x\end{array}$ & 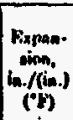 & 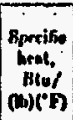 & 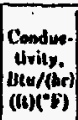 & 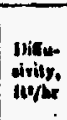 \\
\hline 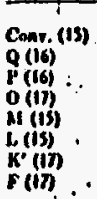 & $\begin{array}{l}333 \\
134 \\
133 \\
210 \\
2126 \\
230 \\
224 \\
233\end{array}$ & 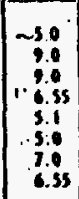 & 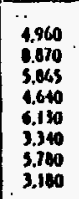 & $\begin{array}{l}630 \\
1.005 \\
200 \\
: 316 \\
118 \\
630 \\
604 \\
406\end{array}$ & $\begin{array}{l}1.6 \\
3.8 \\
3.4 \\
3.3 \\
3.5 \\
3.3 . \\
3.4\end{array}$ & 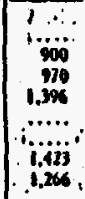 & {$\left[\begin{array}{l}0.011 \\
0.012 \\
0.021 \\
0.023 \\
0.029 \\
0.027 \\
0.018 \\
0.013\end{array}\right.$} & $\begin{array}{l}3.6 \\
10.0 \\
9.1 \\
3.1\end{array}$ & $\begin{array}{l}0.11 \\
: ? ! \\
0.20 \\
0.151 \\
0.116 \\
0.21 \\
0.18\end{array}$ & $\begin{array}{l}1.50 \\
\vdots \cdots \\
1.20 \\
0.04 \\
0.067 \\
1.06 \\
2.75\end{array}$ & $\begin{array}{l}0.012 \\
0.030 \\
0.025 \\
0.026 \\
0.034 \\
0.056\end{array}$ \\
\hline
\end{tabular}

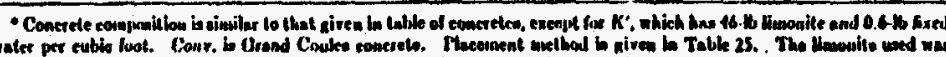

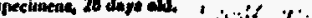
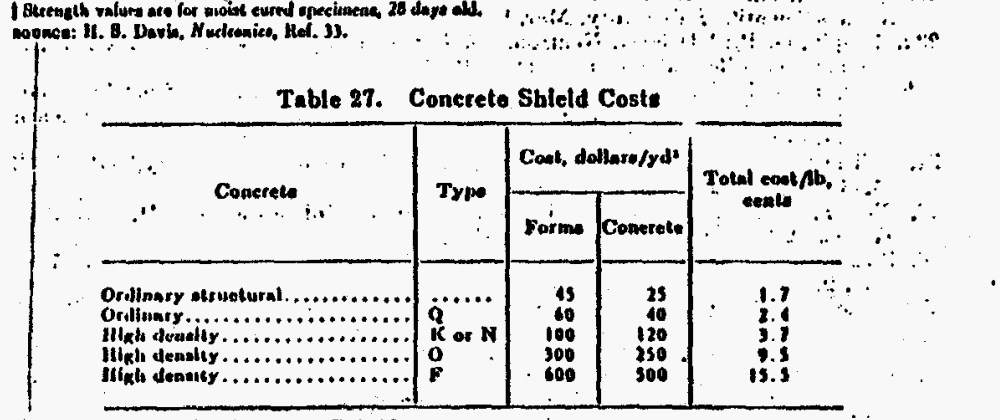

A. 8. Davis, Nuchoonica, Met. 33.

Fruo, U.: Gnmmn-ray Attonuntion, Nucleontec, 11(1): 8 (Auquat, 1953); 11(2): 65 (Soptember, 1053).

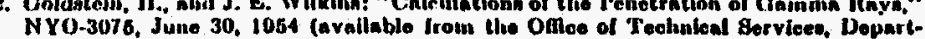

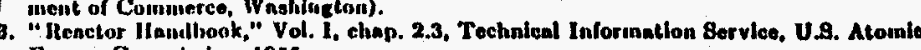
1. Grodstein, Gindya Whito: "X Ray Attanuatlon Coemfolonta from 10 Kor 10100 Mov,"

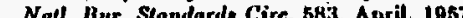

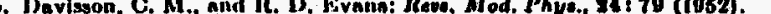

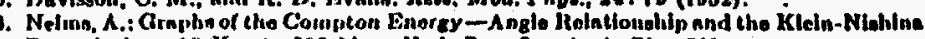

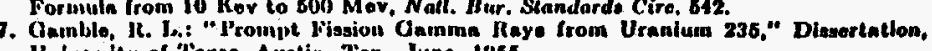

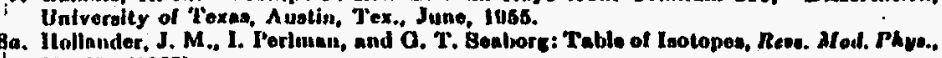

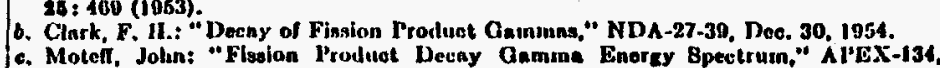
c. Moteff, Jolin: "Flasian I'roduct Decay Gamena Emorgy Bpectrutn," A I'EX-134, d

d. Way, It., et al "Nuclear Dala," Natl. Bur. Standarde Cire. 109 and Bupplemente 1

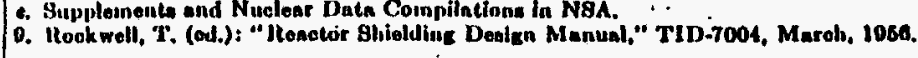


WHC-SD-SNF-PTR-001, Rev. 0

$6 / 16 / 93$

To Dave Hedengren

From: DD Lanning

Subject: Estimated Temperature vs. Time for T-Plant Pool Heatup

Reference: Letter, ER Gilbert/DDL to Hedengren, 12/7/92: "Interim Report on T-Plant Chiller Option Task"

In the reference, equations were given for evaporation and conduction heat loss from the T-Plant PWR fuel pool, as functions pool temperature. These equations were used to graphically solve for the estimated "stabilized" temperature range. Within this range ( 82 to $\left.88^{\circ} \mathrm{F}\right)$ heat losses from the uncooled pool are projected to balance the assumed residual heat production by the Shippingport fuel elements.

These same heat loss expressions could be used in the lumped parameter differential equation for pool temperature vs. time, i.e.:

$d C V d T / d t=$ heat production - heat loss,

where: $d=$ water density

$C=$ water specific heat

$V=$ water volume

$T=$ water temperature

$t=$ time

This equation could then be solved (i.e., integrated) analyticaliy or numerically, to obtain the pool temperature as function of time. The analytical solution is too complex for me to solve (since the evaporation heat loss is a complex function of temperature). However, I have obtained a sensible numerical solution, which is plotted and tabulated on the attached sheets. Note that the solution asymptotically approaches the limits of the stabilized range found earlier in the reference.

This solution is being transmitted to you simply for information, and to confirm our previous estimates that up to two months might be required to achieve stabilized pool temperatures, following the shutdown of the pool water cooling system. You may wish to pass this along to T-Plant personnel. Anyway, it's a freebie. 
Estimated Heatup of

T-Plant PWR Fuel Pool

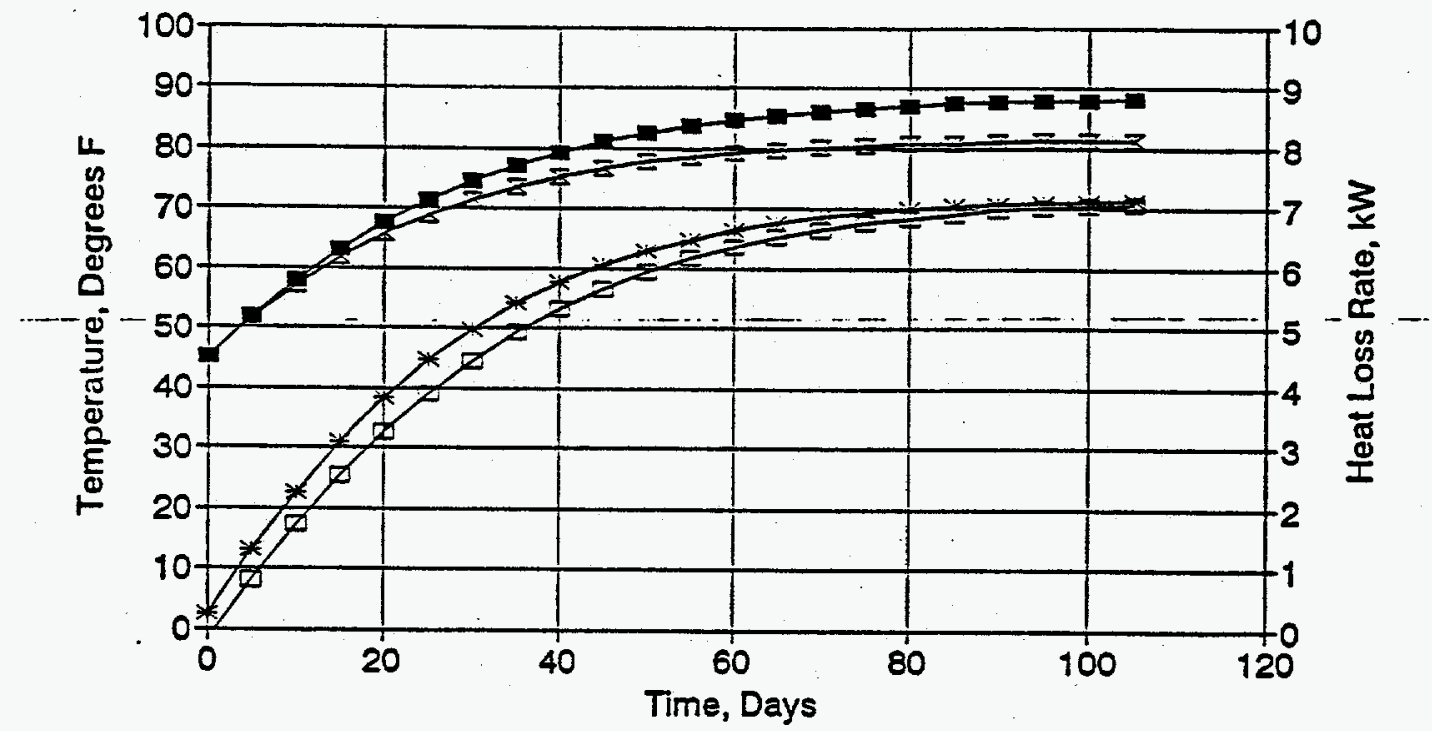

$\rightarrow$ Max. Temp. $=$ Min. Temp. $\quad$ - Max. Ht.Loss $=$ Min.Ht.Loss 
- WHC-SD-SNF-PTR-001, Rev. 0

Estimated Heatup Rate of

T-Plant PWR Fuel Pool

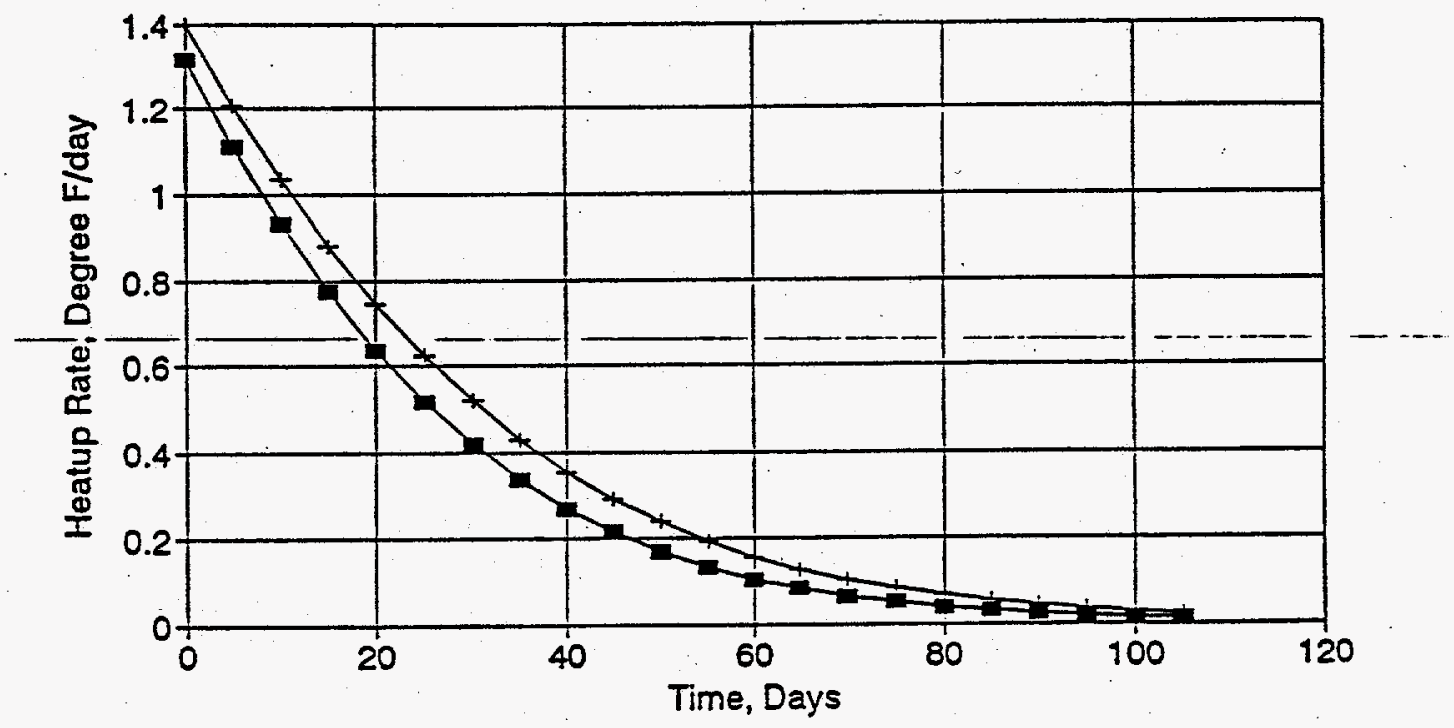

$\rightarrow$ - Min.Rate T Max Rate

A.13 
Estimate of Temp Rise vs. Time in T-Plant PWR Fuel storage Pool

Time, Min. Min. Days

Temp. Temp.

Max.

Max.

Evap. Total

Kelvins Ht.Loss Ht.Loss Ht. Loss (or gain $\mathrm{kW}$

A

B

c

c

E

Rate

$\mathrm{kW}$

Min

Avg.

Temp.

Rise Rate

Time,

Dg.F/day

Days

45.0

51.6

57.1

61.8

280

$-1.10$

$-0.38$

1.34

0.24

0.75

1.18

65.7

287

290

292

68.9

293

295

73.6

296

75.3

297

76.6

298

298

77.7

299

79.2

299

79.7

300

80.1

300

80.5

300

80.7

80.9

300

81.1

300

300

81.2

300

81.3

300

1.53

1.81

2.04

2.23

2.38

2.50

2.59

2.66

2.72

2.77

2.80

2.83

2.85

2.87

2.88

2.89

300

2.90

1.69

2.35

2.65

2.92

3.16

3.37

3.54

3.69

3.81

3.90

3.98

4.04

4.09

4.13

4.16

4.19

4.21

4.22

4.23

4.24

0.24

1.31

2.26

3.09

3.82

4.45

4.97

5.41

5.77

6.07

6.30

6.49

6.64

6.76

6.86

6.93

6.99

7.04

7.07

7.10

7.12

7.14

$\begin{array}{lr}1.32 & 0 \\ 1.11 & 5 \\ 0.93 & 10 \\ 0.78 & 15 \\ 0.64 & 20 \\ 0.52 & 25 \\ 0.42 & 30 \\ 0.34 & 35 \\ 0.27 & 40 \\ 0.21 & 45 \\ 0.17 & 50 \\ 0.13 & 55 \\ 0.11 & 60 \\ 0.08 & 65 \\ 0.06 & 70 \\ 0.05 & 75 \\ 0.04 & 80 \\ 0.03 & 85 \\ 0.02 & 90 \\ 0.02 & 95 \\ 0.01 & 100 \\ 0.01 & 105\end{array}$

H

10

15

25

35

40

45

55

60

65

80

85

95

105

\section{A. 14}


WHC-SD-SNF-PTR-001，ReV. 0

\begin{tabular}{|c|c|c|c|c|c|}
\hline $\begin{array}{l}\text { Max. } \\
\text { Temp. } \\
\text { dg. F }\end{array}$ & $\begin{array}{l}\text { Max } \\
\text { Temp. } \\
\text { Kelvin }\end{array}$ & $\begin{array}{l}\text { Cond. } \\
\text { Ht.Loss } \\
\text { kw }\end{array}$ & $\begin{array}{l}\text { Min. } \\
\text { Evap. } \\
\text { Ht. Loss } \\
\text { kw } \\
\text { I }\end{array}$ & $\begin{array}{c}\text { Min } \\
\text { Total Hea } \\
\text { Loss } \\
\text { kw } \\
\text { M }\end{array}$ & $\begin{array}{l}\text { Max } \\
\text { Avg. } \\
\text { Temp. } \\
\text { Rise Rate } \\
\text { dg. F/day } \\
\text { N }\end{array}$ \\
\hline $\begin{array}{l}45.0 \\
52.0 \\
58.0 \\
63.2 \\
67.6 \\
71.3 \\
74.5 \\
77.1 \\
79.2 \\
81.0 \\
82.5 \\
83.6 \\
84.6 \\
85.4 \\
86.0 \\
86.6 \\
87.0 \\
87.3 \\
87.6 \\
87.8 \\
88.0 \\
88.1\end{array}$ & $\begin{array}{l}280 \\
284 \\
287 \\
290 \\
293 \\
295 \\
297 \\
298 \\
299 \\
300 \\
301 \\
302 \\
302 \\
303 \\
303 \\
303 \\
304 \\
304 \\
304 \\
304 \\
304 \\
304\end{array}$ & $\begin{array}{l}-1.10 \\
-0.33 \\
0.33 \\
0.90 \\
1.39 \\
1.80 \\
2.14 \\
2.43 \\
2.66 \\
2.86 \\
3.02 \\
3.15 \\
3.26 \\
3.35 \\
3.42 \\
3.47 \\
3.52 \\
3.56 \\
3.59 \\
3.61 \\
3.63 \\
3.64\end{array}$ & $\begin{array}{l}0.91 \\
1.14 \\
1.39 \\
1.63 \\
1.87 \\
2.10 \\
2.30 \\
2.49 \\
2.65 \\
2.80 \\
2.92 \\
3.02 \\
3.11 \\
3.18 \\
3.24 \\
3.29 \\
3.32 \\
3.36 \\
3.38 \\
3.40 \\
3.42 \\
3.44\end{array}$ & $\begin{array}{l}-0.19 \\
0.81 \\
1.72 \\
2.54 \\
3.26 \\
3.89 \\
4.45 \\
4.92 \\
5.32 \\
5.66 \\
5.94 \\
6.17 \\
6.36 \\
6.52 \\
6.65 \\
6.76 \\
6.84 \\
6.91 \\
6.97 \\
7.01 \\
7.05 \\
7.08\end{array}$ & $\begin{array}{l}1.40 \\
1.21 \\
1.04 \\
0.88 \\
0.74 \\
0.62 \\
0.52 \\
0.43 \\
0.36 \\
0.29 \\
0.24 \\
0.19 \\
0.16 \\
0.13 \\
0.10 \\
0.08 \\
0.07 \\
0.05 \\
0.04 \\
0.04 \\
0.03 \\
0.02\end{array}$ \\
\hline
\end{tabular}




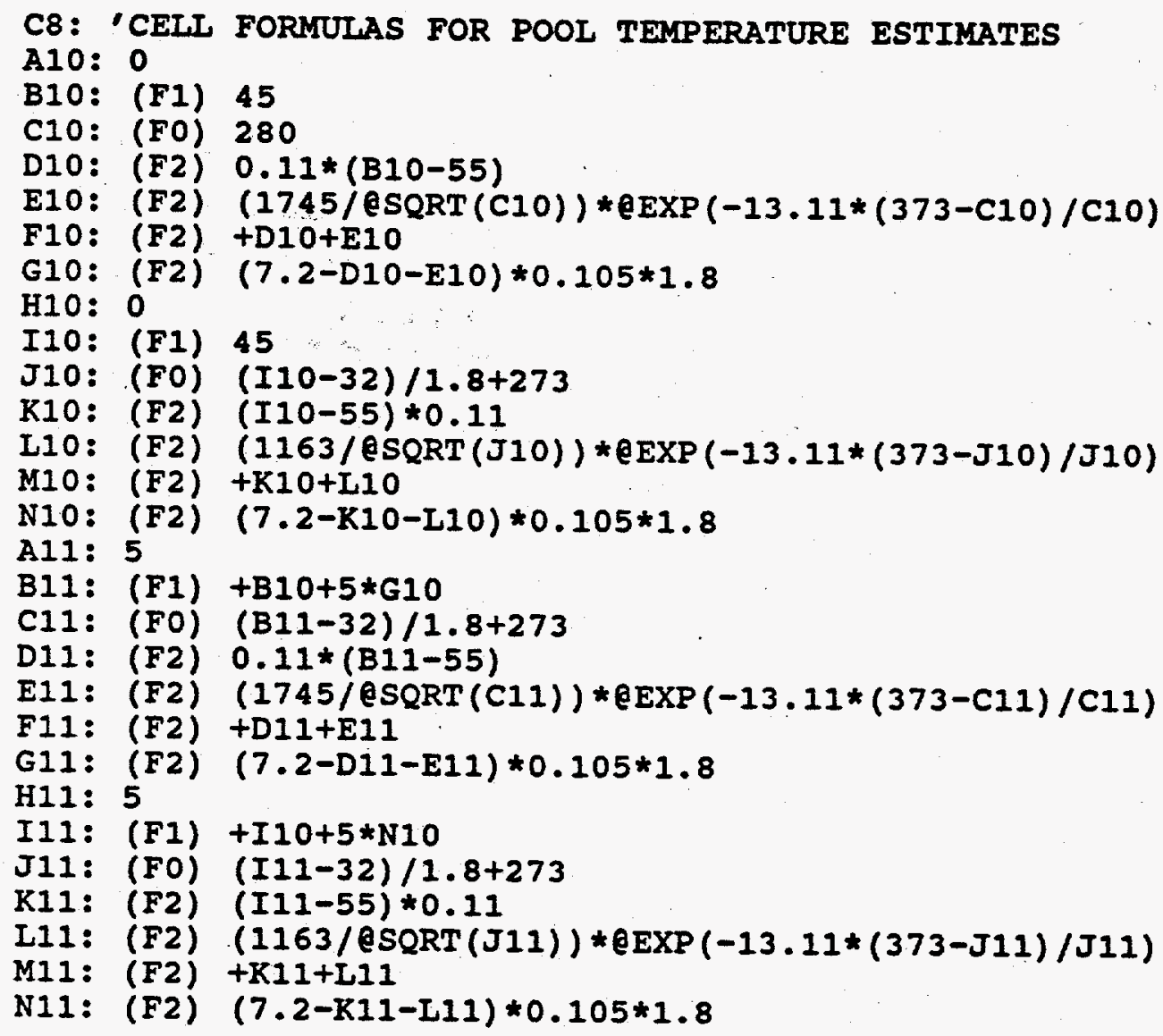

